\title{
Toxicological characterisation of two novel selective aryl hydrocarbon receptor modulators in Sprague-Dawley rats
}

\section{Mahiout, Selma}

2017-07-01

Mahiout, S, Linden , J , Esteban , J , Sanchez-Perez , I , Sankari , S , Pettersson , L , Håkansson , H \& Pohjanvirta , R 2017 , ' Toxicological characterisation of two novel selective aryl hydrocarbon receptor modulators in Sprague-Dawley rats ' , Toxicology and Applied Pharmacology , vol. 326 , pp. 54-65 . https://doi.org/10.1016/j.taap.2017.04.020

http://hdl.handle.net/10138/234476

https://doi.org/10.1016/j.taap.2017.04.020

cc_by_nc_nd

acceptedVersion

Downloaded from Helda, University of Helsinki institutional repository.

This is an electronic reprint of the original article.

This reprint may differ from the original in pagination and typographic detail.

Please cite the original version. 


\section{Toxicological characterisation of two novel selective aryl hydrocarbon receptor modulators in Sprague-Dawley rats}

Selma Mahiouta ${ }^{a}$, Jere Lindén ${ }^{b}$, Javier Estebann ${ }^{c}$, Ismael Sánchez-Pérezc ${ }^{c}$, Satu Sankarid ${ }^{d}$, Lars Petterssone,

a Department of Food Hygiene and Environmental Health, Faculty of Veterinary Medicine, University of Helsinki, Finland

${ }^{b}$ Department of Basic Veterinary Sciences, Faculty of Veterinary Medicine, University of Helsinki, Finland

c Instituto de Bioingeniería, Universidad Miguel Hernández de Elche, Elche, Alicante, Spain

d Central Laboratory of the Department of Equine and Small Animal Medicine, Faculty of Veterinary Medicine, University of Helsinki, Finland

e Immunahr AB, Lund, Sweden

f Institute of Environmental Medicine (IMM), Karolinska Institutet, Stockholm, Sweden

Corresponding author: Selma Mahiout

Dept. of Food Hygiene and Environmental Health, Faculty of Veterinary Medicine

Mustialankatu 1, Fl-00790 Helsinki, Finland

Email: selma.mahiout@helsinki.fi

Phone: 00358-2941-57427

Fax: 00358-2941-57161

Preliminary results of some of the data were presented at $50^{\text {th }}$ Congress of the European Societies of Toxicology (Eurotox 2014), 7-10 September 2014, Edinburgh, Scotland, UK; Society of Toxicology's $55^{\text {th }}$ Annual Meeting, 13-17 March 2016, New Orleans, LA, USA (SOT 2016) and AHR Conference 2016: The Aryl Hydrocarbon Rec eptor as a Central Mediator of Health and Disease, 3-6 August 2016, Rochester, NY, USA. 


\section{Abstract}

The aryl hydrocarbon receptor (AHR) mediates the toxicity of dioxins, but also plays important physiological roles. Selective AHR modulators, which elicit some effects imparted by this receptor without causing the marked toxicity of dioxins, are presently under intense scrutiny. Two novel such compounds are IMA-08401 (N-acetyl-N-phenyl-4-acetoxy-5-chloro-1,2-dihydro-1-methyl-2-oxoquinoline-3-carboxamide) and IMA-07101 (N-acetyl-N-(4-trifluoromethylphenyl)-4-acetoxy-1,2dihydro-5-methoxy-1-methyl-2-oxo-quinoline-3-carboxamide). They represent, as diacetyl prodrugs, AHR-active metabolites of the drug compounds laquinimod and tasquinimod, respectively, which are intended for the treatment of autoimmune diseases and cancer. Here, we toxicologically assessed the novel compounds in Sprague-Dawley rats, after a single dose $(8.75-92.5 \mathrm{mg} / \mathrm{kg})$ and 5-day repeated dosing at the highest doses achievable (IMA-08401: $100 \mathrm{mg} / \mathrm{kg} /$ day; and IMA-07101: $75 \mathrm{mg} / \mathrm{kg} /$ day). There were no overt clinical signs of toxicity, but body weight gain was marginally retarded, and the treatments induced minimal hepatic extramedullary haematopoiesis. Further, both the absolute and relative weights of the thymus were significantly decreased. Cyp1a1 gene expression was substantially increased in all tissues examined. The hepatic induction profile of other AHR battery genes was distinct from that caused by TCDD. The only marked alterations in serum clinical chemistry variables were a reduction in triglycerides and an increase in 3-hydroxybutyrate. Liver and kidney retinol and retinyl palmitate concentrations were affected largely in the same manner as reported for TCDD. In vitro, the novel compounds activated CYP1A1 effectively in H4IIE cells. Altogether, these novel compounds appear to act as potent activators of the AHR, but lack some major characteristic toxicities of dioxins. They therefore represent promising new selective AHR modulators.

\section{Keywords: AH-receptor; selective modulators; IMA-08401; IMA-07101; TCDD; toxicity}




\section{Introduction}

The aryl hydrocarbon receptor (AHR) is an evolutionarily ancient, ligand-activated transcription factor (Beischlag, et al. 2008). It regulates the activity of various genes in different cell types across all vertebrates, and is well known and extensively studied as the mediator of toxicity induced by a class of environmental contaminants called dioxins [polychlorinated dibenzo-para-dioxins (PCDDs), polychlorinated dibenzofurans (PCDFs) and dioxin-like polychlorinated biphenyls (PCBs); reviewed, for example, in (Hahn and Karchner 2011, Mandal 2005)]. More recently, evidence about the importance of the AHR in numerous physiological phenomena has started to emerge, thus revealing its potential as a target for novel pharmacological therapies in several fields. Known endogenous functions of the AHR so far include, for instance, participation in the metabolism of xenobiotics; regulation of reproduction, development, cell growth and differentiation; and modulation of autoimmunity [reviewed for example in (Esser, et al. 2009, Fuji-Kuriyama and Kawajiri 2010, McMillan and Bradfield 2007)]. Furthermore, recent studies have revealed a role for the AHR in the control of intestinal microbiota and innate immunity (Kiss, et al. 2011, Lee, et al. 2012, Moura-Alves, et al. 2014).

The molecular mechanism of AHR action has been revealed in detail for transcriptional induction of a drug-metabolising enzyme, CYP1A1, which is believed to represent a more general pattern, known as the canonical pathway of AHR signalling. In its inactive state, the AHR is located in the cytosol in association with the chaperone proteins HSP90, XAP2 and p23. Binding of a ligand such as 2,3,7,8tetrachlorodibenzo- $p$-dioxin (TCDD) triggers transformation in the protein structure causing the AHR to translocate into the nucleus. There it sheds the cytosolic protein partners and dimerizes with a structurally related protein, ARNT. The AHR-ARNT dimer then binds to the DNA at specific enhancer sites called dioxin response elements (DREs) in the promoter region of the Cyp1a1 gene, eventually leading to induced transcription of CYP1A1 mRNA (Ma 2011). This is a fairly rapid and highly sensitive marker for AHR activation (Abraham, et al. 1988). CYP1A1 activity in vivo can result in metabolic activation of potentially genotoxic compounds such as polycyclic aromatic hydrocarbons (Shimada and 
111

112

113

114

115

116

117

118

119

120

121

122

123

124

125

126

127

128

129

130

131

132

133

134

135

136

Fujii-Kuriyama 2004), but the predominant consequence of its enhanced activity seems to be protective due to augmented detoxification capacity (Nebert, et al. 2004). Additional consequences of elevated CYP1A1 activity include changes in the metabolism of a variety of endogenous molecules with signalling properties, e.g. retinoids (Lampen, et al. 2000, Shmarakov 2015), steroid hormones (Spink, et al. 1992) and, apparently, polyunsaturated fatty acids (Hankinson 2016). Further, unlike previously presumed, Cyp1a1 induction does not automatically indicate dioxin-like toxicity (Hu, et al. 2007, Pohjanvirta, et al. 2011).

TCDD is the most toxic dioxin and has, as such, been widely employed in research as a classical compound for activation of the AHR (Van Den Berg, et al. 1998). As dioxins in general, it is chemically highly persistent and hydrophobic, which leads to its accumulation in the food chain (Travis and Hattemer-Frey 1991). TCDD causes a multitude of adverse effects in laboratory animals including hypophagia, wasting syndrome, developmental toxicity, endocrine disruption, carcinogenicity and immunotoxicity (Pohjanvirta and Tuomisto 1994). The current consensus is that these ultimately result from inappropriate and untimely activation of the AHR (Bock and Köhle 2006, Denison, et al. 2011). However, some of the biological impacts of TCDD are such that they could be potentially beneficial in the treatment of certain diseases, if they could be separated from the toxicity. These impacts are particularly related to immunomodulation (Zhu, et al. 2014). Appropriate activation of AHR, devoid of TCDD-like toxicity, could thus lead to novel therapeutics for treatment of, for instance, cancer, multiple sclerosis (MS), inflammatory skin diseases, Crohn's disease and colitis (Arsenescu, et al. 2011, Benson and Shepherd 2011, Díaz-Díaz, et al. 2016, Furumatsu, et al. 2011, Haas, et al. 2016, Jin, et al. 2014, Quintana, et al. 2008, Van Den Bogaard, et al. 2013).

Selective AHR modulators, which elicit some desired effects imparted by AHR without causing the marked toxicity of dioxins, are presently under intense scrutiny (Safe, et al. 2013). This is in part due to their potential as novel pharmacological compounds, but also because they could be useful tools in 
137

138

139

140

141

142

143

144

145

146

147

148

149

150

151

152

153

154

155

156

the quest of further elucidating the molecular mechanisms at play in the biological and toxicological roles of the AHR. Two recently introduced such molecules are IMA-08401 (later referred to as C2; Fig. 2) and IMA-07101 (later C4). They represent novel diacetyl prodrugs of AHR-active $N$-hydrogen metabolites of the immunomodulatory drug compounds laquinimod and tasquinimod, which are intended for treatment of MS and prostate cancer, respectively (Isaacs, et al. 2006, Polman, et al. 2005). In vivo, the prodrugs $C 2$ and $C 4$ readily hydrolyse to provide the deacetylated active compounds IMA-06201 (C1) and IMA-06504 (C3; unpublished data). The chemical relationships between the prodrug $\mathrm{C} 2$, laquinimod and the AHR-active form $\mathrm{C} 1$ are depicted in Fig. 1. C1 and C3 have previously been shown to be effective AHR activators in vitro [(Pettersson 2012) and unpublished data], but they are unsuitable for in vivo formulations due to their low aqueous solubility. Therefore, little information exists on the activity and toxicity of these compounds in vivo thus far. Here, the short-term toxicity of C2 and C4 was assessed in Sprague-Dawley (S-D) rats and compared with properties earlier established in the literature for TCDD. Both acute (single exposure) and subacute (daily dosing on five consecutive days) toxicities were studied. In addition, the AHR activation potential of the active compounds $\mathrm{C} 1$ and C3 relative to TCDD was screened in vitro by measuring CYP1A1 enzyme activity in the rat hepatoma cell line H4IIE. 


\section{Materials and Methods}

\subsection{Chemicals}

The test compounds C1 (IMA-06201; N-ethyl-N-phenyl-5-chloro-1,2-dihydro-4-hydroxy-1-methyl-2oxo-quinoline-3-carboxamide,; CAS Registry Number: 879410-94-3; Fig. 2), C2 (IMA-08401; N-acetylN-phenyl-4-acetoxy-5-chloro-1,2-dihydro-1-methyl-2-oxo-quinoline-3-carboxamide; CAS: 1373260-173), C3 (IMA-06504; N-(4-trifluoromethylphenyl)-1,2-dihydro-4-hydroxy-5-methoxy-1-methyl-2-oxoquinoline-3-carboxamide; CAS: 1373259-57-4) and C4 (IMA-07101; N-acetyl-N-(4trifluoromethylphenyl)-4-acetoxy-1,2-dihydro-5-methoxy-1-methyl-2-oxo-quinoline-3-carboxamide; CAS: 1373259-76-7) were synthetized as described by Pettersson (2012). C2 and C4 stock solutions for the in vivo studies were prepared by mixing the compounds with PEG-400 (Ph. Eur. grade, SigmaAldrich, St. Louis, MO, USA) and heating them in $+80^{\circ} \mathrm{C}$ water bath for $1 \mathrm{~h}$, with intermittent vortexing. Dilutions were prepared from the stocks with PEG-400. For in vitro study stock solutions, C1, C3 and TCDD were dissolved in DMSO (Sigma-Aldrich). C3 in DMSO was heated in $+65^{\circ} \mathrm{C}$ water bath for 45 min to dissolve. TCDD was purchased from Ufa-Institute (Ufa, Russia) and was over $98 \%$ pure as assessed by gas chromatography-mass spectrometry. The stock solutions were further diluted with cell culture medium before application to cells.

\section{-------- Fig. 2 approximately here}

\subsection{Animals and their husbandry}

S-D rats (males, $\sim 9$ weeks of age at exposures) were purchased from Harlan Netherlands. The rats were acclimatised to study conditions and handling for a minimum of one week after arrival, and were housed in groups of two or three in individually ventilated cages (Sealsafe IVC Blue Line, Techniplast, West Chester, PA, USA) throughout the studies. The rats were maintained on a $12-\mathrm{h}$ light/dark cycle. The lights came on at 6 a.m., and during the night the room was lit with a dim red light. The cage floor 
was covered with aspen wood bedding (Tapvei, Estonia), and each cage enriched with a transparent red plastic hiding tube, nesting material and chew blocks (both aspen wood, Tapvei, Estonia). Commercial pelleted rat chow [RM1 (E) SQC Expanded; SDS Diets, Witham, Essex, England; 8554.27 International units vitamin A/kg diet] and filtered, UV-irradiated tap water were available ad libitum. The animal room was air-conditioned, the temperature kept at $22 \pm 1^{\circ} \mathrm{C}$ and relative humidity at $38-$ 75\% (typically 50\%).

All studies were authorized by the National Animal Experiment Board in Finland (Eläinkoelautakunta, ELLA; project licence code: ESAVI/6882/04.10.03/2012). All procedures were conducted in accordance with the Directive 2010/63/EU of the European Parliament and of the Council.

\subsection{Experimental design}

Within the experiments, rats were randomly allocated into groups, which were matched for body weight (BW). In both experiments, the rats were weighed immediately before exposures and dosed intragastrically by oral gavage according to BW. The compounds were administered after a 3-h fast, for which rats were moved into identical but clean cages, where only water was available for the duration of the fast. After exposures, the fast was further continued for $3 \mathrm{~h}$. At the end of the studies, carbon dioxide was used for euthanasia.

An acute toxicity study was carried out as a pilot experiment to make sure that the novel compounds $\mathrm{C} 2$ and $\mathrm{C} 4$ would not cause marked acute toxicity before their repeated administration to larger groups of rats. The study principle was loosely based on the OECD test guideline for acute oral toxicity [Upand-Down-Procedure (OECD 2008)] to reduce the number of animals required. Estimation of LD50 values proved impossible because of the low toxicity and poor solubility of the compounds (see Results). Three different dose levels were tested for both compounds, the high doses being limited by 
the maximum solubility of the compounds achieved ( $18.5 \mathrm{mg} / \mathrm{ml}$ for $\mathrm{C} 2$ and $\sim 15 \mathrm{mg} / \mathrm{ml}$ for C4). For $\mathrm{C} 2$, the dose levels tested were $8.75(n=1), 17.5(n=1), 30(n=2)$ and $92.5 \mathrm{mg} / \mathrm{kg}(n=3)$. For $C 4$, the dose levels were $8.75(n=2), 27.5(n=2)$ and $75 \mathrm{mg} / \mathrm{kg}(\mathrm{n}=3)$. In addition, there was a control group $(\mathrm{n}=6)$ that received the vehicle (PEG-400).

The single exposures were started by administering the low dose of $17.5 \mathrm{mg} / \mathrm{kg}$ of $\mathrm{C} 2$ to a single rat at a volume of $10 \mathrm{ml} / \mathrm{kg}$ (day 0 ). As at $24 \mathrm{~h}$ after the exposure the rat seemed otherwise healthy but its faeces were runny [a known possible side effect of PEG-400 (Hermansky, et al. 1995, Ueda, et al. 2011)], the volume administered for the rest of the rats was lowered to $5 \mathrm{ml} / \mathrm{kg}$, which ameliorated the diarrhoea. Three days later (day 3), the exposures were continued with $8.75 \mathrm{mg} / \mathrm{kg}$ of C2 (n=1), 30 $\mathrm{mg} / \mathrm{kg}$ of C2 ( $\mathrm{n}=2), 8.75 \mathrm{mg} / \mathrm{kg}$ of $\mathrm{C} 4(\mathrm{n}=2)$, and the vehicle for the control group ( $\mathrm{n}=4)$. After $48 \mathrm{~h}$ (day 5), a further two control rats received the vehicle and rats of the experimental groups the test compounds as follows: $27.5 \mathrm{mg} / \mathrm{kg} \mathrm{C4}(\mathrm{n}=2), 75 \mathrm{mg} / \mathrm{kg} \mathrm{C4}(\mathrm{n}=3)$ and $92.5 \mathrm{mg} / \mathrm{kg} \mathrm{C2}(\mathrm{n}=3)$. All rats were observed individually at least once during the first 30 min after dosing, and periodically thereafter during the first $24 \mathrm{~h}$, with special attention given in the first $4 \mathrm{~h}$. Each rat was also weighed and monitored daily for any clinical signs of toxicity, before being euthanised (on day 7-13 after exposure). After euthanasia, the thymus and liver were excised and weighed.

A subacute toxicity study explored the properties and toxicities of C2 and C4 after repeated administrations on five consecutive days. Five to six males were used per group. On the first day of exposures, the rats weighed $277 \pm 12 \mathrm{~g}(\mathrm{n}=17$; mean \pm SD). The substances were dosed at the highest concentrations attainable (which had proven to be not acutely toxic in the pilot experiment): 100 $\mathrm{mg} / \mathrm{kg} /$ day for $\mathrm{C} 2$ and $75 \mathrm{mg} / \mathrm{kg} /$ day for $\mathrm{C} 4$. The volume administered was $5 \mathrm{ml} / \mathrm{kg}$. The control group was treated with the same volume of the vehicle (PEG-400). After dosing, the rats were observed individually at least once during the first 30 min and periodically thereafter during the first $24 \mathrm{~h}$, with special attention given during the first $4 \mathrm{~h}$. They were weighed daily starting from the first day of 
exposure (day 0), and after the last exposure they were further monitored for five days (until day 9) for any clinical signs. The rats were fasted for $5-10 \mathrm{~h}$ prior to euthanasia, which started at $\sim 12.30 \mathrm{p} . \mathrm{m}$. and finished within $6 \mathrm{~h}$ (animals of the three groups were euthanised in a rotating order). The thymus, liver, kidneys, testes and spleen were weighed. Serum, liver, duodenum, kidney, lung and testis samples were frozen in liquid nitrogen for further processing, and in addition samples from liver, spleen, kidney, lung and both testes were collected for histopathology.

\subsection{Histopathology}

Histological samples from the subacute toxicity study (liver, spleen, kidney, lung and testis) were fixed in $4 \%$ buffered formalin, embedded in paraffin and sectioned at $4 \mu \mathrm{m}$ thickness. Slides were stained with hematoxylin-eosin for histopathological analysis. Microscopic findings were classified with standard pathological nomenclature and the severities of findings were graded on a scale of 1 to 4 as minimal, mild, moderate or marked, respectively. The grades of severity for microscopic findings were subjective; minimal was the least extent discernible. Microscopic findings that are not usually graded were listed as present.

\subsection{Clinical chemistry}

Clinical chemistry analyses following the subacute study were carried out at the Central Laboratory of the Department of Equine and Small Animal Medicine Helsinki, Finland. Enzymatic methods were used for the determination of serum free fatty acids (FFA; a.k.a. long-chain fatty acids [LCFA] or nonesterified fatty acids [NEFA]) (NEFA-C, Waco Chemicals GmbH, Neuss, Germany) and D-3hydroxybutyrate (3-HB; RANBUT, Randox Laboratories Ltd. Crumlin, UK). The analyses were performed with an automatic chemistry analyser (KONE Pro Selective Chemistry Analyser, Thermo Fisher Scientific, Vantaa, Finland). 
The rest of the serum analytes were analysed using the reagents and adaptations recommended by the manufacturer of the automatic chemistry analyser (Konelab 30i, Thermo Fisher Scientific, Vantaa, Finland). The activities of alanine aminotransferase [ALAT; (Schumann, et al. 2002a)] and aspartate aminotransferase [ASAT; (Schumann, et al. 2002b)] were measured according to the reference method of International Federation of Clinical Chemistry and Laboratory Medicine (IFCC 2002/5 and IFCC 2002/6). Total bilirubin was measured by a modified acid diazo coupling method [Malloy-Evelyn; (Parviainen 1997)], creatinine by a kinetic, colorimetric method with alkaline picrate [method of Jaffe; (Fabiny and Ertingshausen 1971)], and glucose enzymatically with glucose oxidase and a modified Trinder colour reaction (Trinder 1969). Triglyceride, cholesterol and urea concentrations were determined by enzymatic methods (Allain, et al. 1974, Gutmann and Bergmeyer 1974, Wahlefeld 1974).

\subsection{RNA isolation and RT-qPCR}

Total RNA was extracted from the liver, duodenum, kidney, lung and testes in the subacute study. For the isolation, Sigma GenElute ${ }^{\mathrm{TM}}$ Mammalian Total RNA Miniprep Kit was used according to the manufacturer's protocol (Sigma-Aldrich, St. Louis, MO, USA). RNA was then treated with Ambion ${ }^{\circledR}$ TURBO DNA-free ${ }^{\mathrm{TM}}$ DNase treatment and removal reagent (Life Technologies, Carlsbad, CA, USA). The concentration of total RNA was measured with a Nanodrop UV Spectrophotometer (Thermo Fisher Scientific, Waltham, MA, USA) and RNA purity verified by $260 / 280$ and $260 / 230 \mathrm{~nm}$ ratios. Total RNA was reverse transcribed to CDNA at $50^{\circ} \mathrm{C}$ for $1 \mathrm{~h}$ using M-MLV RT RNase $\mathrm{H}$ - Point Mutant (Promega, Fitchburg, WI, USA). For each reaction ( $25 \mu \mathrm{l}), 100 \mathrm{U}$ of the enzyme and $800 \mathrm{ng}$ of RNA were used. Realtime quantitative PCR (HOT FIREPol ${ }^{\circledR}$ EvaGreen ${ }^{\circledast}$ qPCR Mix Plus (no ROX), Solis Biodyne, Tartu, Estonia) was performed on the RotorGene 3000 instrument (Qiagen, Hilden, Germany) to determine the mRNA levels of the AHR-battery xenobiotic metabolising enzyme genes: Cyp1a1, Cyp1a2, Cyp1b1, Ahrr, Nqo1, Tiparp, Ugt1a and Cyp2b1. This was carried out by absolute quantification using total RNA amount (20 ng/reaction) for normalization (see Supplementary Table 1 for information on primers) (Bustin 2002, 
Tichopad, et al. 2009). If the qRT-PCR result was below the detection limit, a conservative approach was taken and the sample given the value of the limit.

For comparison of gene expression with TCDD-treated Long-Evans (Turku/AB; L-E; $\mathrm{n}=5$ per group) and Han-Wistar rats (Kuopio; H/W; $\mathrm{n}=5$ per group), existing cDNA samples from a previous study were used (Lindén, et al. 2014). RT-qPCR on these samples was performed with the same primers and in the same conditions, but for statistical analysis, the data were treated separately. This comparison with the S-D rats used in the current study was deemed justified, as both L-E and S-D rats represent TCDD-sensitive rat strains with little difference in their overt responses to TCDD as regards adult exposures [the respective LD50 values are 18 and $43 \mu \mathrm{g} / \mathrm{kg}$, while for TCDD-resistant $\mathrm{H} / \mathrm{W}$ rats the LD50 is > 9600 $\mu \mathrm{g} / \mathrm{kg}$ (Pohjanvirta, et al. 1993, Stahl, et al. 1992, Unkila, et al. 1994)]. Further, the AHR-mediated induction of xenobiotic-metabolising enzymes is exhibited by all rat strains in the same fashion, including $\mathrm{H} / \mathrm{W}$ rats (Franc, et al. 2008).

\subsection{Thyroxine (T4) detection by ELISA}

Thyroxine (T4) levels were measured in sera from the subacute study according to manufacturer's instructions using the Rat Thyroxine T4 ELISA Kit (Cusabio Biotech Co. Ltd, Wuhan, China).

\section{Concentrations of all-trans-retinoic acid, 9-cis-4-oxo-13,14-dihydro-retinoic acid (9-cis-4-oxo-13,14-} dh-retinoic acid), 13-cis-retinoic acid, 4-hydroxy-all-trans-retinoic acid (4-OH-all-trans-retinoic acid), retinol and retinyl palmitate were measured in liver, kidney, and serum samples from the subacute study. The different retinoid forms, extracted from tissue homogenates or serum, were separated on HPLC, and detected by UV at $340 \mathrm{~nm}$ for retinoic acid derivatives (Schmidt, et al. 2003a), and at 325 
$\mathrm{nm}$ for retinol and retinyl palmitate (van der Ven, et al. 2009), i.e. the polar and apolar retinoid forms respectively. Briefly, and as reported previously (Schmidt, et al. 2003a), $300 \mathrm{mg}$ of tissue was homogenised with $300 \mu \mathrm{L}$ of water, and liquid-liquid extraction of retinoids in $400 \mu \mathrm{L}$ of tissue homogenate or serum was performed with isopropanol. Separation of polar from apolar phase retinoid forms was achieved by solid-phase-extraction using an aminopropyl-phase cartridge (Agilent SampliQ amino, Agilent, Santa Clara, CA, USA). Analytes were separated on a Poroshell 120 EC-C18 column (Agilent) using a binary HPLC system (Agilent 1100 series, Agilent). Retinoid standards included 13-cis- and all-trans-retinoic acid from Sigma-Aldrich (Madrid, Spain), and 4-OH-all-transretinoic acid from Toronto Research Chemicals (Toronto, ON, Canada), while a citretin and retinyl acetate (Sigma-Aldrich) were used as internal standards. The limit of detection (LOD) for liver and kidney retinoid concentrations were $0.5 \mathrm{pmol} / \mathrm{g}$ for 13 -cis-retinoic acid, $0.6 \mathrm{pmol} / \mathrm{g}$ for all-transretinoic acid, $1 \mathrm{pmol} / \mathrm{g}$ for 9-cis-4-oxo-13,14-dh-retinoic acid, and 4-OH-all-trans-retinoic acid, and $5.6 \mathrm{pmol} / \mathrm{g}$ for retinol and retinyl palmitate (Schmidt, et al. 2003a). LOD for serum retinoid concentrations were $0.3 \mathrm{pmol} / \mathrm{ml}$ for all-trans-retinoic acid, $0.4 \mathrm{pmol} / \mathrm{ml}$ for 13 -cis-retinoic acid, 0.6 $\mathrm{pmol} / \mathrm{ml}$ for 9-cis-4-oxo-13,14-dh-retinoic acid, and $4.2 \mathrm{pmol} / \mathrm{ml}$ for retinol and retinyl palmitate (Schmidt, et al. 2003a).

\subsection{Screening of CYP1A1 enzyme activity in H4IIE cells}

CYP1A1 enzyme induction potential was screened in vitro in the H4IIE rat hepatoma cell line to estimate the efficacy of the novel compounds compared with that of TCDD. The cells were acquired from ATCC (H-4-II-E ATCC ${ }^{\circledR}$ CRL1548 $\left.{ }^{\text {TM }}\right)$. They were cultured at $37^{\circ} \mathrm{C}$ and $5 \% \mathrm{CO}_{2}$ in Eagle's Minimum Essential Medium (ATCC, Manassas VA, USA) supplemented with 10\% FBS (Sigma-Aldrich, St. Louis, MO, USA). The experiment was performed in a 96-well plate (Greiner Bio-One GmbH, Kremsmünster, Austria). Cells were seeded at 10,000 cells/well and allowed to equilibrate for about $40 \mathrm{~h}$ prior to exposures. The outer and corner wells were left without cells and filled with PBS in order to avoid the edge effect. The cells were then exposed for $24 \mathrm{~h}$ to $1,5,10$ or $50 \mathrm{nM}$ of $\mathrm{C} 1, \mathrm{C} 3$ or TCDD in culture 
medium, or the vehicle ( $0.1 \%$ of DMSO in culture medium). All exposures were performed in triplicates. CYP1A1 activity was detected with P450-Glo ${ }^{\text {TM }}$ CYP1A1 Assay (Promega, Madison, WI, USA) according to manufacturer's instructions. Subsequently, CellTiter-Glo ${ }^{\circledR}$ Luminescent Cell Viability Assay (Promega) was used to confirm that there were no significant differences between the numbers of viable cells in the wells at the time of detection. MycoAlert ${ }^{\mathrm{TM}}$ Mycoplasma Detection Kit (Lonza Group Ltd, Basel, Switzerland) was used for parallel cells to ensure that the cells used in the experiment were not infected.

\subsection{Data analysis and statistics}

In the single-dose study, BW change and relative organ weights (liver, thymus) were statistically assessed only among control and the highest dosage groups of $\mathrm{H} 2$ and $\mathrm{H} 4$ because of the low number of animals in the middle dose groups. Tothis end, one-way ANOVA followed by Duncan's new multiple range test were used applying the SPSS Statistics software (IBM Corp. Released 2013. IBM SPSS Statistics for Windows, Version 22.0/24.0. Armonk, NY, USA).

For the subacute toxicity study data of organ weights, clinical chemistry parameters and mRNA abundance, statistical analysis was carried out by one-way ANOVA and Student-Newman-Keuls posthoc test. If variances were non-homogeneous in ANOVA (as assessed by Levene's test), those values were log-transformed (which restored homogeneity) and then re-analysed by one-way ANOVA. The level of significance in all statistical analyses was set at $p<0.05$, unless specified otherwise.

Statistical analysis of the mRNA abundance data from the TCDD-treated L-E and H/W rats used for comparison was carried out by Student's t-test for independent samples. The results were verified by Mann-Whitney $U$ test due to small group sizes and some of the data not being normally distributed (as assessed by Shapiro-Wilk's test). 
BW development in the subacute study was statistically analysed using mixed between/within subject

361

362

363

364

365

366

367

368

369

370

371

372

373

374

375

376

377

378

379

380

381

382

two-way ANOVAs. For this purpose, the data were verified for normal distribution by Shapiro-Wilk's test, equality of error variances and covariance matrices was assessed by Levene's and Box's tests, respectively, and the homogeneity of the variances of the differences between all combinations of levels of the within-subjects factor (sphericity) by Mauchly's test. Simple main effects were analysed by univariate ANOVA and the Tukey HSD post-hoc test. The level of significance was set at $p<0.05$ in all other cases except for Box's test where only values $p<0.001$ were considered significant.

Serum thyroxine levels were statistically assessed using Kruskal-Wallis non-parametric ANOVA. As mentioned above, they were determined with an ELISA kit. A scrutiny of the standard curve revealed that the lowest standard yielded absorbances that were incompatible with those of the other ones. Because of this and the fact that we were more interested in possible differences among the groups than actual thyroxine levels per se, we decided to utilize the absorbances themselves in the statistical analysis instead of their converted thyroxine concentrations. This approach was statistically justified as we used a non-parametric approach (Kruskal-Wallis ANOVA) based on rank orders of the values in the experimental and control groups. We further verified the methodology with sera from TCDDsensitive L-E rats collected at 10 days after exposure to $100 \mu \mathrm{g} / \mathrm{kg}$ TCDD or the vehicle (corn oil) (Lindén, et al. 2014). The control samples were run on the same ELISA plate and handled identically to the actual samples, except that the non-parametric test in this case was Mann-Whitney $U$ since only two groups were compared. Based on the absorbance analysis, there was a statistically significant decrease in thyroxine levels caused by TCDD in L-E, which is in line with previous findings (Pohjanvirta, et al. 1989). 
Retinoid concentrations were expressed as mean \pm SD. Pairwise multiple comparisons between exposed and control means were performed by using analysis of variance (ANOVA) and linear contrast tests. Significance was considered for values of $p<0.05$, and tendency for $p<0.1$ in R software version 3.2.3, (R Development Core Team, R Foundation for Statistical Computing, Vienna, Austria). Each retinoid was assessed individually. In addition, Box plots were used for verification of normal distribution.

The luminescence data from the in vitro CYP1A1 activity assay were analysed in two different ways. First, the concentrations were individually and compound-wise compared with the control by Kruskal-

392 Wallis non-parametric ANOVA, considering the significances asymptotic. Therefore, the significances 393 of the pairwise comparisons were not adjusted. Second, the fold-changes were subjected to two-way 394 ANOVA. Because the original data as well as the transformations attempted (log10, natural logarithm, 395 square root and square) all yielded non-homogeneous variances (Levene's test: $p<0.001$ ) and there 396 was slight deviation from normal distribution in one of the datasets (C1, $50 \mathrm{nM}$; Shapiro-Wilk's test: $p=0.015)$, the significance level for the interaction term was set at $p<0.001$. Simple main effects were assessed by multiple pairwise comparisons with Bonferroni's adjustment. 


\section{Results}

\subsection{Acute toxicity}

Acute toxicity was screened by administering single doses of both C2 and C4 at three different dose levels, the highest of which $(92.5 \mathrm{mg} / \mathrm{ml}$ and $75 \mathrm{mg} / \mathrm{ml}$, respectively) were determined by the solubility of the compounds. The only conspicuous clinical sign of toxicity was watery faeces in one individual rat that received the first low dose $(17.5 \mathrm{mg} / \mathrm{kg}$ of $\mathrm{C} 2)$ in the volume of $10 \mathrm{ml} / \mathrm{kg}$, a common side effect of PEG-400 (Hermansky, et al. 1995, Ueda, et al. 2011). Subsequently, the volume administered was lowered to $5 \mathrm{ml} / \mathrm{kg}$ for the other rats, which ameliorated the diarrhoea. There were no further clinical signs of toxicity seen during the experiment at any dose levels tested, which is why the highest doses were selected to be used in the repeated dosing experiment. As the number of rats in each group was low in this experiment $(n=1-3$, except for controls where $n=6)$, data from it should be considered with caution, and statistical evaluation was only performed among control and the highest doses of C2 and C4. However, BW gain at 7 days after exposures appeared to show a slightly delayed trend, reaching statistical significance $(p<0.05)$ for $75 \mathrm{mg} / \mathrm{ml} \mathrm{C4}$. The dose of $92.5 \mathrm{mg} / \mathrm{ml} \mathrm{C2} \mathrm{did} \mathrm{not} \mathrm{differ} \mathrm{from} \mathrm{either}$ control or $75 \mathrm{mg} / \mathrm{ml} \mathrm{C4}$ (Supplementary Table 2). Also, both relative and absolute thymus weights exhibited a decreasing trend, with a statistically significant $(p<0.05)$ relative weight loss of $30 \%$ in both high dose groups compared with controls (Supplementary Table 2). Liver weights showed a slight (10 \%) decrease in the C4 mid- and both high dose groups when compared with controls, but statistical significance was not attained (Supplementary Table 2).

\subsection{Clinical signs of subacute toxicity}

For the evaluation of subacute toxicity, $\mathrm{C} 2$ and $\mathrm{C} 4$ were administered once a day for 5 consecutive days at $100 \mathrm{mg} / \mathrm{kg} / \mathrm{day}$ and $75 \mathrm{mg} / \mathrm{kg} /$ day, respectively. After exposures, the rats were monitored for further 5 days before euthanasia and collection of samples. Contrary to the characteristic wasting syndrome of TCDD, BW gain tended to be only marginally decelerated (Fig. 3). Two-way mixed ANOVA revealed a statistically significant interaction in BW gain between treatment and time $(F[4,28]=3.647$; 
$p=0.016$; partial $\eta^{2}=0.343$ ), and subsequent univariate ANOVAs (followed by the Tukey HSD tests) at

426

427 the three time-points showed that the BW gain of C2 at 9 days (4.7\%) was lower than that of control $(10.1 \% ; p=0.049)$. Further, at repeated exposures, slightly soft faeces were seen in many rats in all groups (including controls) also at $5 \mathrm{ml} / \mathrm{kg}$ of PEG-400. Other than those, there were no conspicuous clinical signs of toxicity in either group, apart from peculiar, transient hyperaemia of the ear pinnae (Supplementary Fig. 1). This change appeared on the first day after the end of the 5-day dosing regimen and persisted for $3-4$ days. There were $3 / 5$ rats in $\mathrm{C} 2$ group and $5 / 6$ rats in $\mathrm{C} 4$ group to display this effect. The severity of the hyperaemia varied among individuals, and mostly both ears were affected $(6-7 / 8)$.

------ Fig. 3 approximately here

\subsection{Changes in AHR-battery gene expression}

In the repeated exposure experiment, Cyp1a1 gene expression was determined in liver, duodenum, kidney, testis and lung, and in addition Cyp1a2, Cyp1b1, Cyp2b1, Ahrr, Nqo1, Tiparp, and Ugt1a mRNA abundances were determined in liver. For comparison of C2 and C4 with TCDD, liver CDNA originating from a previous study (Lindén, et al. 2014) was analysed with the same primers and in the same conditions as the samples from the current study. In the Lindén study, TCDD-sensitive L-E and TCDDresistant $\mathrm{H} / \mathrm{W}$ rats were exposed to a single ig dose of $100 \mu \mathrm{g} / \mathrm{kg}$ TCDD and euthanised on day 10 . This comparison was considered justified, as there is little difference in TCDD-sensitivity between adult S-D and L-E rats [the respective LD50 values are 43 and $18 \mu \mathrm{g} / \mathrm{kg}$, while for $\mathrm{H} / \mathrm{W}$ rats the LD50 is > 9600 $\mu \mathrm{g} / \mathrm{kg}$ (Pohjanvirta, et al. 1993, Stahl, et al. 1992, Unkila, et al. 1994)]. Further, induction of xenobioticmetabolising enzymes is similarly manifested in both sensitive and resistant rat strains (Franc, et al. 2008). 
Cyp1a1 gene expression, a sensitive marker for AHR activation, was substantially increased in all

451

452

453

454

455

456

457

458

459

460

461

462

463

464

465

466

467

468

469

470

471 examined tissues by $\mathrm{C} 2$, and, apart from testis, also by $\mathrm{C} 4$ ( $p<0.05$; Fig. 4 ). Increased gene expression by $\mathrm{C} 2$ in the liver was additionally measured for the AHR-battery genes Cyp1a2, Cyp1b1, Ahrr, Nqo1 and Ugt1a, but by C4 only for Cyp1a2 and Ahrr ( $p<0.05$; Table 1). However, all of the changes were much less pronounced than after a single dose of $100 \mu \mathrm{g} / \mathrm{kg}$ of TCDD. The most conspicuous differences in the induction profiles of TCDD and C2/C4 were discernible in Cyp1b1, Ahrr, Nqo1 and Tiparp, all of which were markedly induced by TCDD but feebly, if at all, by C2/C4 (Table 1).

------- Fig. 4 approximately here

(1)

-------- Table 1 approximately here ---------

(1)

(1)

\subsection{Organ weights}

After the subacute toxicity experiment, the thymus, liver, kidneys, spleen and testes of each animal were weighed, and liver, spleen, kidneys, testes and lung were examined histologically. Thymus was the only studied organ where statisticaly significant changes in weight were seen: both the absolute and relative weights were decreased by $\mathrm{C} 2$ and $\mathrm{C} 4$ alike. In both groups, the relative weights were about $40 \%$ lower than in the control group ( $40 \%$ for C2, and $36 \%$ for the C4 group; one-way ANOVA $p<0.001$; Fig. 5). The slight increases in relative testis weights ( $11 \%$ for $C 2$, and $6 \%$ for $C 4$ ) evaded statistical significance (one-way ANOVA $\mathrm{p}=0.068$ ). 
474

475

476

477

478

479

In the subacute toxicity study, C2 and C4 administration induced minimal hepatic extramedullary myeloid haematopoiesis (EMH; Fig. 6) (Thoolen, et al. 2010). This was observed in 3/5 C2-treated and in 4/5 C4-treated animals; none was present in controls. The very lenient reaction consisted of some tiny ( $<10$ cells) sinusoidal foci and of small portal or perivascular infiltrates in selected animals. In general, the most prevalent were deeply basophilic nucleated erythrocytes and undifferentiated progenitor cells with lesser numbers of immature granulocytes. In addition to EMH, no other significant lesions were noted; some animals amongst both treatment groups and controls exhibited few mixed or lymphocytic cell infiltrates or parenchymal inflammatory foci (Thoolen, et al. 2010). One C4-treated animal showed a mild (micro- and macrovesicular) fatty change without extramedullary haematopoiesis and one C2-treated animal a focal minimal fatty change with minimal EMH. All spleen samples exhibited minimal to moderate EMH of all three lineages (Cesta 2006). In contrast to the liver, the intensity of EMH in the spleen did not, however, correlate with the treatments (Supplementary Table 3). No significant histopathological alterations were detected in the lungs or in the testes.

-------- Fig. 6 approximately here ---------

In the subacute toxicity study, the only marked alteration in serum clinical chemistry variables was a reduction of triglycerides by $\mathrm{C} 2$ (44\%, one-way ANOVA, $p=0.02 ;$ Fig. 7$)$. C4 had a similar effect, but the $30 \%$ decrease caused by it did not reach statistical significance. In addition, there was a statistically significant increase of $86 \%$ in the level of $3-\mathrm{HB}$ by C4 (ANOVA $p=0,045$ ). A similar increase of $58 \%$ by C2 was not statistically significant. 
Thyroxine levels were measured in sera collected upon termination of the subacute toxicity test. There were no statistically significant differences among the groups (ANOVA $p=0,426$; Supplementary Table 4).

\subsection{Retinoid analysis}

505

506

507

508

Analysis of polar and apolar retinoid concentrations in the liver, kidney and serum was performed for the control, C2 and C4 groups after the subacute toxicity experiment. In the liver, statistically significant decreases in concentrations of 4-OH-all-trans-retinoic acid, 9-cis-4-oxo-13,14-dihydro-retinoic acid, and retinyl palmitate were found in both the $\mathrm{C} 2$ and $\mathrm{C} 4$ groups, while the concentrations of $13-c i s$ retinoic acid and retinol were not significantly affected in either group (Table 2). The observed increase in hepatic all-trans retinoic acid concentration was significant in group C2 only. In serum, significant decreases occurred in concentrations of 13-cis-retinoic acid, 9-cis-4-oxo-13,14-dihydro-retinoic acid and retinyl palmitate in both C2 and C4 groups, while retinol concentration was increased by both compounds, and all-trans retinoic acid levels were not affected (Table 2). In the kidney, significant increases were detected in retinol and retinyl palmitate concentrations in both the $\mathrm{C} 2$ and $\mathrm{C} 4$ groups, while the observed increase in renal all-trans retinoic acid level was significant in C2 group only (Table 2). Renal concentrations of 9-cis-4-oxo-13,14-dihydro-retinoic acid were not influenced by the treatments.

The magnitudes of effects caused by $\mathrm{C} 2$ and $\mathrm{C} 4$ in retinoid concentrations were largely comparable. For most retinoid forms analysed, the changes recorded were slightly more pronounced in C2 vs C4 
521 group, in line with the higher dose given of this compound. Two exceptions to this rule were provided

522 by renal retinyl palmitate and serum 13-cis-retinoic acid concentrations which were affected clearly 523 more by C4 than C2.

524

525 Table 2 approximately here

526

\subsection{Screening of CYP1A1 enzyme activity in vitro in H4IIE cells}

528

529
The compounds $\mathrm{C} 1$ and $\mathrm{C} 3$ were screened in vitro in the H4IIE rat hepatoma cell line for their CYP1A1 enzyme induction potential, and compared with that of TCDD. The cells were exposed to $1,5,10$ or 50 $\mathrm{nM}$ of either compound or TCDD for $24 \mathrm{~h}$, after which CYP1A1 activity was assessed by a luminescent method. All of the compounds showed a statistically significant induction of CYP1A1 (ANOVA p<0.005), which increased in a dose-dependent fashion (Fig. 8). Apart from the dose level of $1 \mathrm{nM}$, each concentration of the compounds increased CYP1A1 induction in a statistically significant manner when compared with the control group (Fig. 8). In two-way (compound $x$ concentration) ANOVA on the foldchange data, the interaction term proved significant $\left[F(6,57)=7.883, p=3 E-6\right.$, partial $\left.\eta^{2}=0.454\right]$. Subsequent analysis of simple main effects showed that at all concentrations but the lowest one (1 $n M)$, TCDD differed from both $\mathrm{C} 1$ and $\mathrm{C} 3$ in a statistically significant manner $(\mathrm{p}<0.05)$. 


\section{Discussion}

542

543

544

545

546

547

548

549

550

551

552

553

554

555

556

557

558

559

560

561

562

563

564

565

The AHR is notorious for mediating the toxic effects of TCDD and other related environmentally persistent organic pollutants, both in laboratory animals and humans. Based on epidemiological data, exposure to high levels of dioxins is in humans associated with an overall elevation in cancer risk and chloracne, while much lower exposure levels within sensitive time-windows may cause endocrine disruption, altered sex ratios of offspring and lowered quality of sperm (White, et al. 2011). Less evident but still possible adverse health effects include type 2 diabetes and reproductive effects such as increased risk for infertility. In laboratory animals, characteristic adverse effects also include alterations in blood lipids and thyroid function, and immunological effects, but the epidemiological data for these effects in humans remain conflicting (Bastomsky 1977, Fletcher, et al. 2005, Gorski and Rozman 1987, Kerkvliet 2011, Pohjanvirta, et al. 1989, White, et al. 2011). The current consensus is that the adverse effects of dioxins are a consequence of untimely and protracted activation of the AHR, while its appropriate activation is in fact fundamental for normal development and function of all vertebrates, especially for the balanced action of immune system (Bock and Köhle 2006, Denison, et al. 2011, Fernandez-Salguero, et al. 1995, Harrill, et al. 2013). Thus, compounds that could activate the AHR without causing toxicity could have great potential as pharmaceuticals, which could form a basis for novel treatments of diseases in several fields. Here, we characterised toxicological properties of two such candidate compounds, abridged $\mathrm{C} 2$ and $\mathrm{C} 4$, which are intended as novel selective modulators of the AHR. Their properties were studied in S-D rats, both after a single and 5-day repeated dosing, and in H4IIE cells.

The aim of the single dose experiment was to verify that the acute toxicity of the compounds was so low that they could be administered repeatedly. The experiment confirmed that, as during its performance there were no apparent clinical signs of toxicity. However, at the highest dose of both compounds $(n=3)$, thymus size was significantly diminished and a tendency towards dampened growth was evident. Yet, because the numbers of animals used at each dose level in this experiment were low 
in accordance with the modified Up-and-Down procedure applied (OECD 2008), the conclusions drawn from it were regarded as indicative. Therefore, all of the results discussed below are from the 5-day repeated dosing experiment, unless otherwise specified.

Although the exposure period to the compounds in the subacute toxicity experiment was short ( 5 days), the animals were administered the highest doses practically achievable, and therefore it can be expected to have revealed the short-term toxic potential of the test compounds, in particular as to any sensitive endpoints. While the rats overall tolerated the treatments well, the compounds were not without effect. As assessed by their ability to induce hepatic Cyp1a1 gene expression, a fairly rapid and highly sensitive marker for AHR activation (Abraham, et al. 1988), both C2 and C4 appeared to be effective compounds, although apparently either not as much so as TCDD, or the effect was not equally long-lasting. A single dose of $0.1 \mathrm{mg} / \mathrm{kg}$ TCDD used previously in the study by Lindén et al. (2014) brought about, even 10 days after the exposure, more prominent hepatic induction of Cyp1a1: 1100fold in the TCDD-sensitive L-E strain and 860-fold in the TCDD-resistant H/W strain. Here, doses of 100 $\mathrm{mg} / \mathrm{kg} /$ day and $75 \mathrm{mg} / \mathrm{kg} /$ day for $\mathrm{C} 2$ and $\mathrm{C} 4$, respectively, administered daily on days $0-4$, resulted in 370- and 140-fold inductions, when similarly measured in samples taken on day 9 (the molecular weights of $C 2$ and $C 4$ are $30-50 \%$ higher than that of TCDD). However, the true in vivo induction potencies of $\mathrm{C} 2$ and $\mathrm{C} 4$ may be greater than suggested by the findings of the present study, since the 5-day recovery period included may have markedly influenced the resultant gene expression levels measured. In support of this notion, 1-50 nM concentrations of $\mathrm{C} 1$ and especially $\mathrm{C} 3$ (the respective, active metabolites of $\mathrm{C} 2$ and $\mathrm{C4}$, intended for in vitro assays) induced responses closer to the same fold-range as TCDD in the 24h CYP1A1 enzyme activity screening assay in the H4IIE rat hepatoma cell line in vitro (Fig. 8). Moreover, in our previous in vivo study, even a single dose of $4 \mathrm{mg} / \mathrm{kg} \mathrm{C2}$ induced hepatic Cyp1a1 expression 1700-fold compared with controls, when liver was sampled already at $28 \mathrm{~h}$ after exposure (Mahiout and Pohjanvirta 2016). Collectively, these findings imply a rapid and probably inducible elimination of C2 and C4 in S-D rats, with an elimination half-life within a range of hours to a 
593

594

595

596

597

598

599

600

601

602

603

604

605

606

607

608

609

610

611

612

613

614

615

616

617

618

couple of days for repeated exposure. This may also account for the variability seen in Cyp1a1 induction data (Fig. 4), reflecting inter-individual differences in elimination rates of the compounds.

In addition to Cyp1a1, both compounds also induced here several other AHR-battery genes of xenobiotic metabolism, but the induction profiles were distinct for TCDD and C2/C4 (Table 1). In this regard, especially Ahrr and Cyp1b1 clearly stood out. Of special interest is also the lack of Ugt1 induction by $\mathrm{C} 2 / \mathrm{C} 4$, because the reduction in serum thyroxine caused by TCDD chiefly emanates from accelerated thyroxine catabolism by liver UGT1A6 (Nishimura, et al. 2005), and C2/C4 failed to influence circulating thyroxine concentrations (see below). Overall, the results resembled those of Cyp1a1 activation in the sense that C2 appeared somewhat more effective than C4, and TCDD clearly more so than the two novel compounds. The difference between C2 and C4 is likely, at least partly, due to the dissimilarity of the doses used, which were dictated by the solubility of the compounds. This view is reinforced by the in vitro CYP1A1 induction results presented here, as well as by our yet unpublished in vitro data on these compounds (manuscript in preparation), which revealed that in fact $\mathrm{C} 3$ consistently appeared somewhat more effective than $\mathrm{C} 1$. As for the differences between $\mathrm{C} 2 / \mathrm{C} 4$ and TCDD, a likely explanation lies in pharmacokinetics. After all, TCDD is well-known for its very low biodegradability, also in rats (Pohjanvirta, et al. 1990), which in turn leads to persistent activation of the AHR, enabling major toxicities to emerge. Hence, for pharmaceutical use, C2 and C4 appear to be much better-suited in this respect.

The likelihood that $\mathrm{C} 2$ and $\mathrm{C} 4$ are metabolised and excreted much more efficiently than TCDD should not lead to the assumption that they would be without other discernible effects than activation of metabolic pathways. Indeed, there were also other characteristic effects that appear to be quite similar between both $C 2 / C 4$ and TCDD, even if somewhat less pronounced by the novel compounds: thymic atrophy, changes in tissue retinoid (vitamin A) concentrations and, as we previously reported for $\mathrm{C2}$, novel food avoidance (Fletcher, et al. 2001, Gupta, et al. 1973, Harris, et al. 1973, Lensu, et al. 2011a, 
Mahiout and Pohjanvirta 2016, Tuomisto, et al. 2000). Thymic atrophy is one of the most consistent and uniform effects of TCDD across mammalian species (Pohjanvirta and Tuomisto 1994). It mainly stems from depletion of small immature cortical thymocytes (Vos, et al. 1974) by a mechanism which may involve impeded maturation of T-lymphocyte precursors (Greenlee, et al. 1985, Holladay, et al. 1991), enhanced apoptosis (McConkey, et al. 1988), and impaired thymic seeding by prothymocytes (Fine, et al. 1990). TCDD also weakens both cell-mediated and humoral-mediated immunity, increasing susceptibility to infectious diseases and transplanted tumours (Luebke, et al. 2006, Pohjanvirta and Tuomisto 1994).

As to retinoid homeostasis, retinol and retinyl palmitate concentrations in the liver, kidney and serum were affected in the same manner by $\mathrm{C} 2$ and $\mathrm{C} 4$. Of these, the hepatic and renal changes, along with the substantial diminution in 9-cis-4-oxo-13,14-dihydro-retinoic acid levels in the liver, were also reminiscent of those seen after short-term TCDD exposure in male rats (Hoegberg, et al. 2003, Nilsson, et al. 2000, Schmidt, et al. 2003b). However, the decrease detected in serum retinyl palmitate concentration in C2- and C4-treated rats is not a typical effect of TCDD, and high TCDD doses have been reported to elevate serum all-trans-retinoic acid levels (Hoegberg, et al. 2003, Nilsson, et al. 2000, Schmidt, et al. 2003b), while this retinoid species remained unaltered following C2 or C4 exposure. It should also be noted that there are not enough data in the literature on the effect of TCDD on several of the retinoic acid derivatives in the tissues that were analysed in the present study. In particular, data are lacking on the effect of TCDD on 4-OH-all-trans- or 13-cis-retinoic acid in rat tissues. Therefore, no firm conclusions can be drawn yet on the full extent to which the alterations induced by $\mathrm{C} 2$ and $\mathrm{C} 4$ resemble those of TCDD.

All of the effects mentioned above are classified as type I, and are thus responses that are similar in both TCDD-sensitive L-E and TCDD-resistant H/W rat strains (Pohjanvirta, et al. 2011). In this rat strain model of TCDD toxicity, TCDD resistance is based on an altered transactivation domain structure in the 
645

646

647

648

649

650

651

652

653

654

655

656

657

658

659

660

661

662

663

664

665

666

667

668

669

670

AHR of the resistant $H / W$ strain. This change results in an at least 100 -fold difference in TCDD doses required to elicit certain responses in L-E vs. H/W rats (type II effects). As a corollary, it means that type I effects, which emerge at the same doses in both strains, are robust to structural variations in AHR transactivation domain and thereby represent more generic AHR-mediated impacts. As a rule, type II effects occur at higher doses of TCDD than type l effects, although exceptions exist. In this light, it is interesting that there are also several typical toxic effects of TCDD that are lacking altogether with $\mathrm{C} 2$ and $\mathrm{C4}$, at least at the doses used here: hypercholesterolemia and reduced plasma thyroxine levels (both type I effects); acute lethality, wasting syndrome, grave liver and testis lesions, hypoglycaemia, and elevated plasma FFA levels (all type II effects) (Pohjanvirta, et al. 2011, Viluksela, et al. 1999). Hence, these novel AHR activators bring about only a subset of the response spectrum previously reported to TCDD, and all those effects belong to type I category. Whether any of type II responses would manifest if higher doses of $\mathrm{C} 2$ or C4 could be administered is a matter of speculation. However, the slight downward tendency recorded in BWs in the present study might suggest that the existence of early alterations in the adverse outcome pathway that ultimately culminates to the wasting syndrome cannot be totally ruled out.

On the other hand, it is noteworthy that $\mathrm{C} 2$ and $\mathrm{C} 4$ also induced effects that have not been reported with TCDD. These included a conspicuous ear hyperaemia, minimal EMH in the liver, a reduction of serum triglycerides and an increase of serum 3-HB. The ear hyperaemia appears perplexing, as it has not been reported previously as a clinical response to AHR activators. There was no visible injury to the skin, nor any clinical sign of infection. The hyperaemia might suggest a transient disturbance of either systemic or local thermoregulation, or be due to changes in blood pressure or vasodilatation. Further studies are needed to resolve its pathogenesis. EMH has been reported on post-natal day 14 in the livers of mice exposed to TCDD in utero (Weinstein, et al. 2008), but to the best of our knowledge, not in animals exposed to TCDD at adult age. However, a multitude of factors (including xenobiotics) which cause e.g. local hypoxia, bone marrow failure or myelotoxicity can elicit it in laboratory animals, 
671

672

673

674

675

676

677

678

679

680

681

682

683

684

685

686

687

688

689

690

691

692

693

694

695

696

most frequently in spleen but also in liver (Chiu, et al. 2015). In the present case, it is tempting to link it with the auricular hyperaemia, because both could represent a response to tissue hypoxia. In serum, the concomitant decrease of triglycerides and elevation of 3-HB point to enhanced $\beta$-oxidation at the expense of lowered de novo fatty acid biosynthesis in the liver. The interference of TCDD with hepatic lipid metabolism is unclear at present, because there is evidence in favour of accelerated (Muzi, et al. 1989, Potter, et al. 1986), decelerated (Christian, et al. 1986), and unaltered (Tomaszewski, et al. 1988) $\beta$-oxidation rate in rats treated with TCDD at doses capable of causing the wasting syndrome. In any case, serum ketone bodies typically remain unaffected (Pohjanvirta and Tuomisto, 1994), and thus these novel AHR activators stand out from the dioxin-like toxicity pattern in this respect.

Moreover, there are some characteristic adverse effects common to TCDD exposure that we did not look into in these experiments due to technical reasons, and thus information about the effects of $\mathrm{C} 2$ and $\mathrm{C} 4$ on these is, for the time being, lacking completely. These include further effects on the endocrine system, such as changes in testosterone, insulin or melatonin levels; changes in the degree of oxidative stress in various tissues; bone and tooth lesions; immuno- and developmental toxicity; and carcinogenicity. In adult rats, reduction of serum thyroxine appears to be one of the most sensitive endocrine indicators of exposure to TCDD with an $\mathrm{ED}_{50}$ between 1 and $5 \mu \mathrm{g} / \mathrm{kg}$ in S-D rats (Viluksela, et al. 2004). Hence, the fact that its levels appear to be unaffected by $C 2$ and $C 4$ could predict that there would be few if any effects on other hormone levels either, but this should naturally be tested in the future, as well as the possible existence of the other effects that were missing here.

In addition to the AHR mediating immunotoxic effects, it has also been identified as part of a molecular pathway of physiological immune responses, and thus as a target for immunomodulatory therapies [reviewed in (Zhu, et al. 2014)]. Disease models in which AHR modulation has been suggested as a possible target include, for instance, cancer, Crohn's disease, ulcerative colitis, diabetes, MS and inflammatory skin conditions such as atopic dermatitis (Benson and Shepherd 2011, Díaz-Díaz, et al. 
2016, Furumatsu, et al. 2011, Haas, et al. 2016, Jin, et al. 2014, Kerkvliet, et al. 2009, Quintana, et al. 2010, Singh, et al. 2007, Van Den Bogaard, et al. 2013). Although the mechanisms of action of the parent compounds of $\mathrm{C} 1$ and $\mathrm{C} 3$, laquinimod and tasquinimod, are not yet fully elucidated, they are recognised as immunomodulatory compounds (Raymond, et al. 2014, Varrin-Doyer, et al. 2014). Moreover, the immunomodulatory mode of action of laquinimod, which produces low but persistent levels of $\mathrm{C} 1$, has been shown to be AHR dependent in the mouse Experimental Autoimmune Encephalomyelitis (EAE) MS model (Berg, et al. 2016, European Medicines Agency 2014, Kaye, et al. 2016). Further, $\mathrm{C} 1$ is a more potent inhibitor of disease development in the EAE model than laquinimod (European Medicines Agency 2014). Finally, substantially higher levels of C1 are generated in vivo from C2 than from laquinimod (unpublished results). Therefore, it would be of high interest to study the likely effects that $\mathrm{C} 2$ and $\mathrm{C} 4$ have on the immune system in the future. So far, the only information is from the EAE model in rats, where $\mathrm{C} 2$ (total dose $4 \mathrm{mg} / \mathrm{kg}$, sc) efficiently prevented EAE development (Pettersson 2012) and from unpublished data on its ameliorating effects in the dextran sulfate sodium -induced colitis model in mice $(1 \mathrm{mg} / \mathrm{kg}, \mathrm{po})$.

In conclusion, it appears clear that these novel compounds are potent activators of the AHR, but lack some major characteristic toxic effects of TCDD. In addition, overall their observed effect profiles seem distinct from that of TCDD, and pharmacokinetics is likely to play a role in this. It is also possible that they have lower binding affinities to the AHR, or occupy a different position in the ligand-binding domain of the protein (Denison, et al. 2011); these would be interesting to explore in the future. Whether these compounds are capable of causing type II effects of TCDD at all would also be worth studying further. Nevertheless, based on our findings, both C2 and C4 appear to represent promising new selective AHR modulators. 
722 Supplementary Table 1 Primer sequences and amplification efficiencies in RT-qPCR runs.

723 Supplementary Table 2 Body weight gain and relative thymus and liver weights in the acute toxicity 724 study.

725 Supplementary Table 3 Observed EMH in the spleen across groups in the subacute toxicity study.

726 Supplementary Table 4 Serum thyroxine absorbances in the subacute toxicity study.

727 Supplementary Fig. 1 Photos of transient hyperaemia in the ears after 5-day repeated dosing.

\section{Acknowledgements}

731 The work was financially supported by Academy of Finland (Grant no. 261232; to RP) and University of 732 Helsinki Doctoral Programme in Food Chain and Health of the Doctoral School in Environmental, Food 733 and Biological Sciences (to SM). We further wish to acknowledge Susanna Lukkarinen for her valuable technical contribution in processing samples and performing RT-qPCR. The staff at Laboratory Animal Centre (LAC) of the University of Helsinki is thanked for their cooperation and help with practicalities; we especially thank Leena Liesirova, Anna Meller, Virpi Ahokas and Lea Karvonen for having provided help whenever needed. 
740

Abraham, K., Krowke, R., Neubert, D., 1988. Pharmacokinetics and biological activity of 2,3,7,8tetrachlorodibenzo-p-dioxin - 1. Dose-dependent tissue distribution and induction of hepatic ethoxyresorufin O-deethylase in ratsfollowing a single injection. Arch. Toxicol. 62, 359-368.

Allain, C.C., Poon, L.S., Chan, C.S.G., 1974. Enzymatic determination of total serum cholesterol. Clin. Chem. 20, 470-475.

Arsenescu, R., Arsenescu, V., Zhong, J., Nasser, M., Melinte, R., Dingle, R. W.C., Swanson, H., De Villiers, W.J., 2011. Role of the xenobiotic receptor in inflammatory bowel disease. Inflammatory Bowel Dis. 17, 1149-1162.

Bastomsky, C.H., 1977. Enhanced thyroxine metabolism and high uptake goiters in rats after a single dose of 2,3,7,8-tetrachlorodibenzo-p-dioxin. Endocrinology 101, 292-296.

Beischlag, T.V., Morales, J.L., Hollingshead, B.D., Perdew, G.H., 2008. The aryl hydrocarbon receptor complex and the control of gene expression. Crit. Rev. Eukaryotic Gene Expr. 18, 207-250.

Benson, J.M., Shepherd, D.M., 2011. Aryl hydrocarbon receptor activation by TCDD reduces inflammation associated with Crohn's disease. Toxicol. Sci. 120, 68-78.

Berg, J., Mahmoudjanlou, Y., Duscha, A., Massa, M.G., Thöne, J., Esser, C., Gold, R., Haghikia, A., 2016. The immunomodulatory effect of laquinimod in CNS autoimmunity is mediated by the aryl hydrocarbon receptor. J. Neuroimmunol. 298, 9-15.

Bock, K.W., Köhle, C., 2006. Ah receptor: Dioxin-mediated toxic responses as hints to deregulated physiologic functions. Biochem. Pharmacol. 72, 393-404.

Bustin, S.A., 2002. Quantification of mRNA using real-time reverse transcription PCR (RT-PCR): Trends and problems. J. Mol. Endocrinol. 29, 23-39.

Cesta, M.F., 2006. Normal structure, function, and histology of the spleen. Toxicol. Pathol. 34, 455465.

Chiu, S.-., Liu, H.-., Chen, C.-., Chen, P.-., Liu, M.-., Lin, S.-., Chang, K.-., 2015. Extramedullary hematopoiesis $(E M H)$ in laboratory animals: Offering an insight into stem cell research. Cell Transplant. 24, 349-366.

Christian, B.J., Menahan, L.A., Peterson, R.E., 1986. Intermediary metabolism of the mature rat following 2,3,7,8-tetrachlorodibenzo-p-dioxin treatment. Toxicol. Appl. Pharmacol. 83, 360-378.

Denison, M.S., Soshilov, A.A., He, G., Degroot, D.E., Zhao, B., 2011. Exactly the same but different: Promiscuity and diversity in the molecular mechanisms of action of the aryl hydrocarbon (dioxin) receptor. Toxicol. Sci. 124, 1-22.

Díaz-Díaz, C.J., Ronnekleiv-Kelly, S.M., Nukaya, M., Geiger, P.G., Balbo, S., Dator, R., Megna, B.W., Carney, P.R., Bradfield, C.A., Kennedy, G.D., 2016. The aryl hydrocarbon receptor is a repressor of inflammation-associated colorectal tumorigenesis in mouse. Ann. Surg. 264, 429-435.

Esser, C., Rannug, A., Stockinger, B., 2009. The aryl hydrocarbon receptor in immunity. Trends Immunol. 30, 447-454. 

Human Use (CHMP) Nerventra, laquinimod. http://www.ema.europa.eu/docs/en_GB/document_library/EPAR__Public_assessment_report/human/002546/WC500171788.pdf, May 2014.

Fabiny, D.L., Ertingshausen, G., 1971. Automated reaction-rate method for determination of serum creatinine with the CentrifiChem. Clin. Chem. 17, 696-700.

Fernandez-Salguero, P., Pineau, T., Hilbert, D.M., McPhail, T., Lee, S.S.T., Kimura, S., Nebert, D.W., Rudikoff, S., Ward, J.M., Gonzalez, F.J., 1995. Immune system impairment and hepatic fibrosis in mice lacking the dioxin-binding Ah receptor. Science 268, 722-726.

Fine, J.S., Silverstone, A.E., Gasiewicz, T.A., 1990. Impairment of prothymocyte activity by 2,3,7,8tetrachlorodibenzo-p-dioxin. J. Immunol. 144, 1169-1176.

Fletcher, N., Hanberg, A., Håkansson, H., 2001. Hepatic vitamin A depletion is a sensitive marker of 2,3,7,8-Tetrachlorodibenzo-p-dioxin (TCDD) exposure in four rodent species. Toxicol. Sci. 62, 166175.

Fletcher, N., Wahlström, D., Lundberg, R., Nilsson, C.B., Nilsson, K.C., Stockling, K., Hellmold, H., Håkansson, H., 2005. 2,3,7,8-Tetrachlorodibenzo-p-dioxin (TCDD) alters the mRNA expression of critical genes associated with cholesterol metabolism, bile acid biosynthesis, and bile transport in rat liver: A microarray study. Toxicol. Appl. Pharmacol. 207, 1-24.

Franc, M.A., Moffat, I.D., Boutros, P.C., Tuomisto, J.T., Tuomisto, J., Pohjanvirta, R., Okey, A.B., 2008. Patterns of dioxin-altered mRNA expression in livers of dioxin-sensitive versus dioxin-resistant rats. Arch. Toxicol. 82, 809-830.

Fuji-Kuriyama, Y., Kawajiri, K., 2010. Molecular mechanisms of the physiological functions of the aryl hydrocarbon (dioxin) receptor, a multifunctional regulator that senses and responds to environmental stimuli. Proc. Jpn. Acad. Ser. B Phys. Biol. Sci. 86, 40-53.

Furumatsu, K., Nishiumi, S., Kawano, Y., Ooi, M., Yoshie, T., Shiomi, Y., Kutsumi, H., Ashida, H., FujiiKuriyama, Y., Azuma, T., Yoshida, M., 2011. A role of the aryl hydrocarbon receptor in attenuation of colitis. Dig. Dis. Sci. 56, 2532-2544.

Gorski, J.R., Rozman, K., 1987. Dose-response and time course of hypothyroxinemia and hypoinsulinemia and characterization of insulin hypersensitivity in 2,3,7,8-tetrachlorodibenzo-pdioxin (TCDD)-treated rats. Toxicology44, 297-307.

Greenlee, W.F., Dold, K.M., Irons, R.D., Osborne, R., 1985. Evidence for direct action of 2,3,7,8tetrachlorodibenzo-p-dioxin (TCDD) on thymic epithelium. Toxicol. Appl. Pharmacol. 79, 112-120.

Gupta, B.N., Vos, J.G., Moore, J.A., 1973. Pathologic effects of 2,3,7,8 tetrachlorodibenzo p dioxin in laboratory animals. Environ. Health Perspect. 5, 125-140.

Gutmann, I., Bergmeyer, H.U., 1974. Determination of urea with glutamate dehydrogenase as indicator enzyme, in: Bergmeyer, H.U. (Ed.), Methods of Enzymatic Analysis, 2nd English ed. Acad. Press, New York, NY, U.S.A., pp. 1794-1798. 
Haas, K., Weighardt, H., Deenen, R., Köhrer, K., Clausen, B., Zahner, S., Boukamp, P., Bloch, W., Krutmann, J., Esser, C., 2016. Aryl Hydrocarbon Receptor in Keratinocytes Is Essential for Murine Skin Barrier Integrity. J. Invest. Dermatol.

Hahn, M.E., Karchner, S.I., 2011. Structural and Functional Diversification of AHRs during Metazoan Evolution, in: Pohjanvirta, R. (Ed.), The AH Receptor in Biology and Toxicology. John Wiley \& Sons, Inc., Hoboken, NJ, USA, pp. 387-403.

Hankinson, O., 2016. The role of AHR-inducible cytochrome P450s in metabolism of polyunsaturated fatty acids. Drug Metab. Rev. 48, 342-350.

Harrill, J.A., Hukkanen, R.R., Lawson, M., Martin, G., Gilger, B., Soldatow, V., LeCluyse, E.L., Budinsky, R.A., Rowlands, J.C., Thomas, R.S., 2013. Knockout of the aryl hydrocarbon receptor results in distinct hepatic and renal phenotypes in rats and mice. Toxicol. Appl. Pharmacol. 272, 503-518.

Harris, M.W., Moore, J.A., Vos, J.G., Gupta, B.N., 1973. General biological effects of TCDD in laboratory animals. Environ. Health Perspect. 5, 101-109.

Hermansky, S.J., Neptun, D.A., Loughran, K.A., Leung, H.W., 1995. Effects of polyethylene glycol 400 (PEG 400) following 13 weeks of gavage treatment in fischer-344 rats. Food Chem. Toxicol. 33, 139149.

Hoegberg, P., Schmidt, C.K., Nau, H., Ross, A.C., Zolfaghari, R., Fletcher, N., Trossvik, C., Nilsson, C.B., Håkansson, H., 2003. 2,3,7,8-Tetrachlorodibenzo-p-dioxin induces lecithin: Retinol acyltransferase transcription in the rat kidney. Chem. -Biol. Interact. 145, 1-16.

Holladay, S.D., Lindstrom, P., Blaylock, B.L., Comment, C.E., Germolec, D.R., Heindell, J.J., Luster, M.I., 1991. Perinatal thymocyte antigen expression and postnatal immune development altered by gestational exposure to tetrachlorodibenzo-P-dioxin (TCDD). Teratology 44, 385-393.

Hu, W., Sorrentino, C., Denison, M.S., Kolaja, K., Fielden, M.R., 2007. Induction of Cyp1a1 is a nonspecific biomarker of aryl hydrocarbon receptor activation: Results of large scale screening of pharmaceuticals and toxicants in vivo and in vitro. Mol. Pharmacol. 71, 1475-1486.

Isaacs, J.T., Pili, R., Qian, D.Z., Dalrymple, S.L., Garrison, J.B., Kyprianou, N., Björk, A., Olsson, A., Leanderson, T., 2006. Identification of ABR-215050 as lead second generation quinoline-3carboxamide anti-angiogenic agent for the treatment of prostate cancer. Prostate 66, 1768-1778.

Jin, U.H., Lee, S.O., Pfent, C., Safe, S., 2014. The aryl hydrocarbon receptor ligand omeprazole inhibits breast cancer cell invasion and metastasis. BMC Cancer 14:498.

Kaye, J., Piryatinsky, V., Birnberg, T., Hingaly, T., Raymond, E., Kashi, R., Amit-Romach, E., Caballero, I.S., Towfic, F., Ator, M.A., Rubinstein, E., Laifenfeld, D., Orbach, A., Shinar, D., Marantz, Y., Grossman, I., Knappertz, V., Hayden, M.R., Laufer, R., 2016. Laquinimod arrests experimental autoimmune encephalomyelitis by activating the aryl hydrocarbon receptor. PNAS.

Kerkvliet, N.I., Steppan, L.B., Vorachek, W., Oda, S., Farrer, D., Wong, C.P., Pham, D., Mourich, D.V., 2009. Activation of aryl hydrocarbon receptor by TCDD prevents diabetes in NOD mice and increases Foxp3 + T cells in pancreatic lymph nodes. Immunotherapy 1, 539-547.

Kerkvliet, N.I., 2011. TCDD, AHR, and Immune Regulation, in: Pohjanvirta, R. (Ed.), The AH Receptor in Biology and Toxicology. John Wiley \& Sons, Inc., Hoboken, NJ, U.S.A., pp. 277-284. 
Kiss, E.A., Vonarbourg, C., Kopfmann, S., Hobeika, E., Finke, D., Esser, C., Diefenbach, A., 2011. Natural aryl hydrocarbon receptor ligands control organogenesis of intestinal lymphoid follicles. Science 334, 1561-1565.

Lampen, A., Meyer, S., Arnhold, T., Nau, H., 2000. Metabolism of vitamin A and its active metabolite all-trans-retinoic acid in small intestinal enterocytes. J. Pharmacol. Exp. Ther. 295, 979-985.

Lee, J.S., Cella, M., McDonald, K.G., Garlanda, C., Kennedy, G.D., Nukaya, M., Mantovani, A., Kopan, R., Bradfield, C.A., Newberry, R.D., Colonna, M., 2012. AHR drives the development of gut ILC22 cells and postnatal lymphoid tissues via pathways dependent on and independent of Notch. Nat. Immunol. 13, 144-152.

Lensu, S., Tuomisto, J.T., Tuomisto, J., Pohjanvirta, R., 2011a. Characterization of the 2,3,7,8tetrachlorodibenzo-p-dioxin (TCDD)-provoked strong and rapid aversion to unfamiliar foodstuffs in rats. Toxicology $283,140-150$.

Lindén, J., Lensu, S., Pohjanvirta, R., 2014. Effect of 2,3,7,8-Tetrachlorodibenzo-p-dioxin (TCDD) on hormones of energy balance in a TCDD-sensitive and a TCDD-resistant rat strain. Int. J. Mol. Sci. 15, 13938-13966.

Luebke, R.W., Chen, D.H., Dietert, R., Yang, Y., King, M., Luster, M.I., 2006. The comparative immunotoxicity of five selected compounds following developmental or adult exposure. J. Toxicol. Environ. Health Part B 9, 1-26.

Ma, Q., 2011. Overview of AHR Functional Domains and the Classical AHR Signaling Pathway: Induction of Drug Metabolizing Enzymes, in: Pohjanvirta, R. (Ed.), The AH Receptor in Biology and Toxicology. John Wiley \& Sons, Inc., Hoboken, NJ, USA, pp. 33-45.

Mahiout, S., Pohjanvirta, R., 2016. Aryl hydrocarbon receptor agonists trigg er avoidance of novel food in rats. Physiol. Behav. 167, 49-59.

Mandal, P.K., 2005. Dioxin: A review of its environmental effects and its aryl hydrocarbon receptor biology. J. Comp. Physiol. B. 175, 221-230.

McConkey, D.J., Hartzell, P., Duddy, S.K., Håkansson, H., Orrenius, S., 1988. 2,3,7,8Tetrachlorodibenzo-p-dioin kills immature thymoytes by Ca2+-mediated endonudease activation. Science 242, 256-259.

McMillan, B.J., Bradfield, C.A., 2007. The aryl hydrocarbon receptor sans xenobiotics: Endogenous function in genetic model systems. Mol. Pharmacol. 72, 487-498.

Moura-Alves, P., Faé, K., Houthuys, E., Dorhoi, A., Kreuchwig, A., Furkert, J., Barison, N., Diehl, A., Munder, A., Constant, P., Skrahina, T., Guhlich-Bornhof, U., Klemm, M., Koehler, A.-., Bandermann, S., Goosmann, C., Mollenkopf, H.-., Hurwitz, R., Brinkmann, V., Fillatreau, S., Daffe, M., Tümmler, B., Kolbe, M., Oschkinat, H., Krause, G., Kaufmann, S.H.E., 2014. AhR sensing of bacterial pigments regulates antibacterial defence. Nature 512, 387-392.

Muzi, G., Gorski, J.R., Rozman, K., 1989. Mode of metabolism is altered in 2,3,7,8-tetrachlorodibenzop-dioxin (TCDD)-treated rats. Toxicol. Lett. 47, 77-86.

Nebert, D.W., Dalton, T.P., Okey, A.B., Gonzalez, F.J., 2004. Role of aryl hydrocarbon receptormediated induction of the CYP1 enzymes in environmental toxicity and cancer. J. Biol. Chem. 279, 23847-23850. 
Nilsson, C.B., Hoegberg, P., Trossvik, C., Azais-Braesco, V., Blaner, W.S., Fex, G., Harrison, E.H., Nau, H., Schmidt, C.K., van Bennekum, A.M., Hakansson, H., 2000. 2,3,7,8-Tetrachlorodibenzo-p-dioxin increases serum and kidney retinoic acid levels and kidney retinol esterification in the rat. Toxicol. Appl. Pharmacol. 169, 121-131.

Nishimura, N., Yonemoto, J., Miyabara, Y., Fujii-Kuriyama, Y., Tohyama, C., 2005. Altered thyroxin and retinoid metabolic response to 2,3,7,8-tetrachlorodibenzo-p-dioxin in aryl hydrocarbon receptor-null mice. Arch. Toxicol. 79, 260-267.

OECD, 2008. Test no. 425: Acute Oral Toxicity: Up-and-Down Procedure, OECD Guidelines for the Testing of Chemicals, Section 4. OECD Publishing, Paris.

Parviainen, M.T., 1997. A modification of the acid diazo coupling method (Malloy-Evelyn) for the determination of serum total bilirubin. Scand. J. Clin. Lab. Invest. 57, 275-280.

Pettersson, L., 2012. 1,2-Dihydro-4-hydroxy-2-oxo-quinoline-3-carboxanilides as AHR Activators. W02012/050500A1.

Pohjanvirta, R., Kulju, T., Morselt, A. F.W., Tuominen, R., Juvonen, R., Rozman, K., Männistö, P., Collan, Y., Sainio, E.-., Tuomisto, J., 1989. Target tissue morphology and serum biochemistry following 2,3,7,8-tetrachlorodibenzo-p-dioxin (TCDD) exposure in a TCDD-susceptible and a TCDD-resistant rat strain. Fundam. Appl. Toxicol. 12, 698-712.

Pohjanvirta, R., Tuomisto, J., 1994. Short-term toxicity of 2,3,7,8-tetrachlorodibenzo-p-dioxin in laboratory animals: Effects, mechanisms, and animal models. Pharmacol. Rev. 46, 483-549.

Pohjanvirta, R., Unkila, M., Tuomisto, J., 1993. Comparative acute lethality of 2,3,7,8tetrachlorodibenzo-p-dioxin (TCDD), 1,2,3,7,8-pentachlorodibenzo-p-dioxin and 1,2,3,4,7,8hexachlorodibenzo-p-dioxin in the most TCDD-susceptible and the most TCDD-resistant rat strain. Pharmacol. Toxicol. 73, 52-56.

Pohjanvirta, R., Vartiainen, T., Uusi-Rauva, A., Monkkonen, J., Tuomisto, J., 1990. Tissue distribution, Metabolism, and excretion of 14c-tcdd in a tcdd-susceptible and a tcdd-resistant rat straina. Pharmacol. Toxicol. 66, 93-100.

Pohjanvirta, R., Korkalainen, M., Moffat, I.D., Boutros, P.C., Okey, A.B., 2011. Role of the AHR a nd its Structure in TCDD Toxicity, in: Pohjanvirta, R. (Ed.), The AH Receptor in Biology and Toxicology. John Wiley \& Sons, Inc., Hoboken, NJ, USA, pp. 179-196.

Polman, C., Barkhof, F., Sandberg-Wollheim, M., Linde, A., Nordle, O., Nederman, T., 2005. Treatment with laquinimod reduces development of active MRI lesions in relapsing MS. Neurology 64, 987-991.

Potter, C.L., Menahan, L.A., Peterson, R.E., 1986. Relationship of alterations in energy metabolism to hypophagia in rats treated with 2,3,7,8-tetrachlorodibenzo-P-dioxin. Toxicol. Sci. 6, 89-97.

Quintana, F.J., Basso, A.S., Iglesias, A.H., Korn, T., Farez, M.F., Bettelli, E., Caccamo, M., Oukka, M., Weiner, H.L., 2008. Control of Treg and TH17 cell differentiation by the aryl hydrocarbon receptor. Nature 453, 65-71.

Quintana, F.J., Murugaiyan, G., Farez, M.F., Mitsdoerffer, M., Tukpah, A. -., Burns, E.J., Weiner, H.L., 2010. An endogenous aryl hydrocarbon receptor ligand acts on dendritic cells and $T$ cells to suppress experimental autoimmune encephalomyelitis. Proc. Natl. Acad. Sci. U. S. A. 107, 20768-20773. 

tasquinimod on the tumour microenvironment. Cancer Chemother. Pharmacol. 73, 1-8.

Safe, S., Lee, S.-., Jin, U.-., 2013. Role of the aryl hydrocarbon receptor in carcinogenesis and potential as a drug target. Toxicol. Sci. 135, 1-16.

Schmidt, C.K., Brouwer, A., Nau, H., 2003a. Chromatographic analysis of endogenous retinoids in tissues and serum. Anal. Biochem. 315, 36-48.

Schmidt, C.K., Hoegberg, P., Fletcher, N., Nilsson, C.B., Trossvik, C., Håkansson, H., Nau, H., 2003 b. 2,3,7,8-Tetrachlorodibenzo-p-dioxin (TCDD) alters the endogenous metabolism of all-trans-retinoic acid in the rat. Arch. Toxicol. 77, 371-383.

941

942

943

Schumann, G., Bonora, R., Ceriotti, F., Ferard, G., Ferrero, C.A., Franck, P.F., Gella, F.J., Hoelzel, W., Jorgensen, P.J., Kanno, T., Kessner, A., Klauke, R., Kristiansen, N., Lessinger, J.M., Linsinger, T.P., Misaki, H., Panteghini, M., Pauwels, J., Schiele, F., Schimmel, H.G., Weidemann, G., Siekmann, L., International Federation of Clinical Chemistry and Laboratory Medicine, 2002a. IFCC primary reference procedures for the measurement of catalytic activity concentrations of enzymes at 37 degrees $C$. International Federation of Clinical Chemistry and Laboratory Medicine. Part 4. Reference procedure for the measurement of catalytic concentration of alanine aminotransferase. Clin. Chem. Lab. Med. 40, 718-724.

Schumann, G., Bonora, R., Ceriotti, F., Ferard, G., Ferrero, C.A., Franck, P.F., Gella, F.J., Hoelzel, W., Jorgensen, P.J., Kanno, T., Kessner, A., Klauke, R., Kristiansen, N., Lessinger, J.M., Linsinger, T.P., Misaki, H., Panteghini, M., Pauwels, J., Schiele, F., Schimmel, H.G., Weidemann, G., Siekmann, L., International Federation of Clinical Chemistry and Laboratory Medicine, 2002b. IFCC primary reference procedures for the measurement of catalytic activity concentrations of enzymes at 37 degrees C. International Federation of Clinical Chemistry and Laboratory Medicine. Part 5. Reference procedure for the measurement of catalytic concentration of aspartate aminotransferase. Clin. Chem. Lab. Med. 40, 725-733.

Shimada, T., Fujii-Kuriyama, Y., 2004. Metabolic activation of polycyclic aromatic hydrocarbons to carcinogens by cytochromes P450 1A1 and 1B1. Cancer Sci. 95, 1-6.

Shmarakov, I.O., 2015. Retinoid-xenobiotic interactions: the Ying and the Yang. Hepatobiliary. Surg. Nutr. 4, 243-267.

Singh, N.P., Hegde, V.L., Hofseth, L.J., Nagarkatti, M., Nagarkatti, P.S., 2007. Resveratrol (trans-3,5,4'trihydroxystilbene) ameliorates experimental allergic encephalomyelitis, primarily via induction of apoptosis in T cells involving activation of aryl hydrocarbon receptor and estrogen receptor. Mol. Pharmacol. 72, 1508-1521.

Spink, D.C., Eugster, H.-., Lincoln II, D.W., Schuetz, J.D., Schuetz, E.G., Johnson, J.A., Kaminsky, L.S., Gierthy, J.F., 1992. 17ß-Estradiol hydroxylation catalyzed by human cytochrome P450 1A1: A comparison of the activities induced by 2,3,7,8-tetrachlorodibenzo-p-dioxin in MCF-7 cells with those from heterologous expression of the cDNA. Arch. Biochem. Biophys. 293, 342-348.

Stahl, B.U., Kettrup, A., Rozman, K., 1992. Comparative toxicity of four chlorinated dibenzo-p-dioxins (CDDs) and their mixture - Part I: Acute toxicity and toxic equivalency factors (TEFs). Arch. Toxicol. 66, 471-477.

Thoolen, B., Maronpot, R.R., Harada, T., Nyska, A., Rousseaux, C., Nolte, T., Malarkey, D.E., Kaufmann, W., Küttler, K., Deschl, U., Nakae, D., Gregson, R., Vinlove, M.P., Brix, A.E., Singh, B., 
974

975

Belpoggi, F., Ward, J.M., 2010. Proliferative and nonproliferative lesions of the rat and mouse hepatobiliary system. Toxicol. Pathol. 38, 5S-81S.

Tichopad, A., Kitchen, R., Riedmaier, I., Becker, C., Ståhlberg, A., Kubista, M., 2009. Design and optimization of reverse-transcription quantitative PCR experiments. Clin. Chem. 55, 1816-1823.

Tomaszewski, K.E., Montgomery, C.A., Melnick, R.L., 1988. Modulation of 2,3,7,8-tetrachlorodibenzop-dioxin toxicity in F344 rats by di(2-ethylhexyl)phthalate. Chem. -Biol. Interact. 65, 205-222.

Travis, C.C., Hattemer-Frey, H.A., 1991. Human exposure to dioxin. Sci. Total Environ. 104, 97-127.

Trinder, P., 1969. Determination of glucose in blood using glucose oxidase with an alternative oxygen acceptor. Ann. Clin. Biochem. 6, 24-28.

Tuomisto, J.T., Viluksela, M., Pohjanvirta, R., Tuomisto, J., 2000. Changes in food intake and food selection in rats after 2,3,7,8- tetrachlorodibenzo-p-dioxin (TCDD) exposure. Pharmacol. Biochem. Behav. 65, 381-387.

Ueda, Y., Tsuboi, M., Ota, Y., Makita, M., Aoshima, T., Nakajima, M., Narama, I., 2011. Gastric mucosal changes induced by polyethylene glycol 400 administered by gavage in rats. J. Toxicol. Sci. $36,811-815$.

Unkila, M., Pohjanvirta, R., Macdonald, E., Tuomisto, J.T., Tuomisto, J., 1994. Dose Response and Time Course of Alterations in Tryptophan Metabolism by 2,3,7,8-Tetrachlorodibenzo-p-dioxin (TCDD) in the Most TCDD-Susceptible and the Most TCDD-Resistant Rat Strain: Relationship with TCDD Lethality. Toxicol. Appl. Pharmacol. 128, 280-292.

Van Den Berg, M., Birnbaum, L., Bosveld, A.T.C., Brunström, B., Cook, P., Feeley, M., Giesy, J.P., Hanberg, A., Hasegawa, R., Kennedy, S. W., Kubiak, T., Larsen, J.C., Van Leeuwen, F.X.R., Liem, A.K.D., Nolt, C., Peterson, R.E., Poellinger, L., Safe, S., Schrenk, D., Tillitt, D., Tysklind, M., Younes, M., Wærn, F., Zacharewski, T., 1998. Toxic equivalency factors (TEFs) for PCBs, PCDDs, PCDFs for humans and wildlife. Environ. Health Perspect. 106, 775-792.

Van Den Bogaard, E.H., Bergboer, J.G.M., Vonk-Bergers, M., Van Vlijmen-Willems, I.M.J.J., Hato, S.V., Van Der Valk, P.G.M., Schröder, J.M., Joosten, I., Zeeuwen, P.L.J.M., Schalkwijk, J., 2013. Coal tar induces AHR-dependent skin barrier repair in atopic dermatitis. J. Clin. Invest. 123, 917-927.

van der Ven, L.T.M., van de Kuil, T., Leonards, P.E.G., Slob, W., Lilienthal, H., Litens, S., Herlin, M., Håkansson, H., Cantón, R.F., van den Berg, M., Visser, T.J., van Loveren, H., Vos, J.G., Piersma, A.H., 2009. Endocrine effects of hexabromocyclododecane (HBCD) in a one-generation reproduction study in Wistar rats. Toxicol. Lett. 185, 51-62.

Varrin-Doyer, M., Zamvil, S.S., Schulze-Topphoff, U., 2014. Laquinimod, an up-and-coming immunomodulatory agent for treatment of multiple sclerosis. Exp. Neurol. 262, Part A, 66-71.

Viluksela, M., Raasmaja, A., Lebofsky, M., Stahl, B.U., Rozman, K.K., 2004. Tissue-specific effects of 2,3,7,8-tetrachlorodibenzo-p-dioxin (TCDD) on the activity of 5 '-deiodinases I and II in rats. Toxicol. Lett. 147, 133-142.

Viluksela, M., Unkila, M., Pohjanvirta, R., Tuomisto, J.T., Stahl, B.U., Rozman, K.K., Tuomisto, J., 1999. Effects of 2,3,7,8-tetrachlorodibenzo-p-dioxin (TCDD) on liver phosphoenolpyruvate carboxykinase (PEPCK) activity, glucose homeostasis and plasma amino acid concentrations in the most TCDDsusceptible and the most TCDD-resistant rat strains. Arch. Toxicol. 73, 323-336. 
Vos, J.G., Moore, J.A. , Zinkl, J.G., 1974. Toxicity of 2,3,7,8-tetrachlorodibenzo-p-dioxin (TCDD) in C57B1 6 mice. Toxicol. Appl. Pharmacol. 29, 229-241.

1016 Wahlefeld, A.W., 1974. Triglycerides. Determination after enzymatic hydrolysis., in: Bergmeyer, H.U. 1017 (Ed.), Methods of Enzymatic Analysis, 2nd English ed. Acad. Press, New York; NY; U.S.A., pp. 183110181835.

1019 Weinstein, D.A., Gogal Jr., R.M., Mustafa, A., Prater, M.R., Holladay, S.D., 2008. Mid-gestation 1020 exposure of C57BL/6 mice to 2,3,7,8-tetrachlorodibenzo-p-dioxin causes postnatal morphologic changes in the spleen and liver. Toxicol. Pathol. 36, 705-713.

1022 White, S.S., Fenton, S.E., Birnbaum, L.S., 2011. 22. Adverse Health Outcomes Caused By Dioxin1023 Activated AHR in Humans, in: Pohjanvirta, R. (Ed.), The AH Receptor in Biology and Toxicology. John 1024 Wiley \& Sons, Inc., pp. 307-316.

1025 Zhu, C., Xie, Q., Zhao, B., 2014. The role of AhR in autoimmune regulation and its potential as a therapeutic target against CD4 T cell mediated inflammatory disorder. Int. J. Mol. Sci. 15, 10116- 
Table 1 Expression of AHR-batterygenes related to xenobiotic metabolism and Cyp2b1 in S-D rat liver triggered by $\mathrm{C} 2(100 / \mathrm{mg} / \mathrm{kg} / \mathrm{day})$ and $\mathrm{C} 4(75 \mathrm{mg} / \mathrm{kg} /$ day; 5 -day dosing regimen followed by 5 -day monitoring period before euthanasia) vs. controls. For comparison, data from TCDD-treated ${ }^{a}(100$ $\mu \mathrm{g} / \mathrm{kg}$ single dose) L-E and $\mathrm{H} / \mathrm{W}$ rats vs. controls are shown. $(+)=$ Statistically significant induction, $(-)=$ no statistical significance $(p<0.05$, one-way ANOVA/Student-Newman-Keuls or Student's t-test). Fold change ${ }^{b}$ in brackets

\begin{tabular}{lllll}
\hline Gene & C2 & C4 & $\begin{array}{l}\text { TCDD } \\
\text { (L-E) }\end{array}$ & $\begin{array}{l}\text { TCDD } \\
\text { (H/W) }\end{array}$ \\
\hline Cyp1a1 & $+(370)$ & $+(140)$ & $+(1100)$ & $+(860)$ \\
Cyp1a2 & $+(5)$ & $+(2)$ & $+(8)$ & $+(20)$ \\
Cyp1b1 & $+(5)$ & $-(1)$ & $+(1600)$ & $+(500)$ \\
Cyp2b1 & $-(3)$ & $-(1)$ & $+(5)$ & $-(1)$ \\
Ahrr & $+(6)$ & $+(3)$ & $+(230)$ & $+(160)$ \\
Nq01 & $+(3)$ & $-(2)$ & $+(50)$ & $+(15)$ \\
Tiparp & $-(1)$ & $-(1)$ & $+(25)$ & $+(9)$ \\
Ugt1a & $+(1.4)$ & $-(1.2)$ & $+(7)$ & $+(6)$ \\
\hline
\end{tabular}

a The data for the TCDD groups are from a previous study (Lindén, et al. 2014), where TCDD-sensitive L-E and TCDD-resistant H/W rats were exposed to a single ig dose of $100 \mu \mathrm{g} / \mathrm{kg}$ TCDD and euthanised at 10 days. The CDNA for these samples had been reverse-transcribed previously, but qPCR was performed with the same primers and in the same conditions as for $\mathrm{C} 2$ and $\mathrm{C} 4$.

1043

${ }^{b}$ Fold change $=$ the ratio between the mean values for exposed and control rats 
Table 2 Concentrations of retinoids in liver, kidney and serum samples from the subacute study, in which vehicle, C2 (100 mg/kg/day) or C4 ( $75 \mathrm{mg} / \mathrm{kg} /$ day) was administered on 5 consecutive days

\begin{tabular}{|c|c|c|c|c|c|c|}
\hline \multirow[b]{2}{*}{ Liver } & \multirow{2}{*}{$\begin{array}{l}\text { Control } \\
\text { Mean } \pm S D\end{array}$} & \multicolumn{2}{|l|}{$\mathrm{C} 2$} & \multicolumn{2}{|l|}{$\mathrm{C} 4$} & \multirow{2}{*}{$p$-value } \\
\hline & & Mean \pm SD & & Mean \pm SD & & \\
\hline All-trans-retinoic acid (pmol/g) & $11.8 \pm 1.8$ & $15.9 \pm 1.9$ & $* *$ & $14.1 \pm 2.6$ & & 0.020 \\
\hline 13-cis-retinoic acid (pmol/g) & $3.76 \pm 0.67$ & $7.70 \pm 5.11$ & & $4.32 \pm 0.89$ & & 0.080 \\
\hline 4-hydroxy-all-trans-retinoic acid (pmol/g) & $1.65 \pm 0.64$ & $0.52^{b} \pm 0.25$ & *** & $0.55^{b} \pm 0.25$ & *** & 0.001 \\
\hline 9-cis-4-oxo-13,14-dh-retinoic acid (pmol/g) & $58.6 \pm 9.3$ & $4.68 \pm 2.25$ & *** & $3.86 \pm 1.62$ & *** & $<0.001$ \\
\hline Retinol (nmol/g) & $12.7 \pm 1.9$ & $15.9 \pm 3.8$ & & $16.9 \pm 3.6$ & & 0.094 \\
\hline Retinyl palmitate $(\mu \mathrm{mol} / \mathrm{g})$ & $0.74 \pm 0.09$ & $0.41 \pm 0.11$ & *** & $0.52 \pm 0.11$ & ${ }^{* *}$ & $<0.001$ \\
\hline \multicolumn{7}{|l|}{ Serum } \\
\hline All-trans-retinoic acid (pmol/g) & $1.02 \pm 0.28$ & $1.14 \pm 0.34$ & & $1.15 \pm 0.24$ & & 0.687 \\
\hline 13-cis-retinoic acid (pmol/g) & $1.36 \pm 0.30$ & $0.74 \pm 0.16$ & *** & $0.50 \pm 0.14$ & *** & $<0.001$ \\
\hline 9-cis-4-oxo-13,14-dh-retinoic acid (pmol/g) & $3.52 \pm 0.84$ & $1.58 \pm 0.56$ & ** & $2.15 \pm 0.75$ & $* *$ & 0.003 \\
\hline Retinol (nmol/g) & $2.50 \pm 0.19$ & $3.21 \pm 0.24$ & *** & $3.12 \pm 0.15$ & *** & $<0.001$ \\
\hline Retinyl palmitate $(\mathrm{nmol} / \mathrm{g})$ & $0.06 \pm 0.01$ & $0.03 \pm 0.01$ & *** & $0.03 \pm 0.01$ & *** & $<0.001$ \\
\hline \multicolumn{7}{|l|}{ Kidney } \\
\hline All-trans-retinoic acid (pmol/g) & $7.88 \pm 0.60$ & $9.92 \pm 0.94$ & $* *$ & $8.41 \pm 1.03$ & & 0.005 \\
\hline 9-cis-4-oxo-13,14-dh-retinoic acid (pmol/g) & $1.15 \pm 0.44$ & $1.80 \pm 1.00$ & & $1.45 \pm 0.88$ & & 0.423 \\
\hline Retinol (nmol/g) & $7.01 \pm 0.69$ & $9.32 \pm 0.75$ & $* * *$ & $9.10 \pm 0.62$ & *** & $<0.001$ \\
\hline Retinyl palmitate (nmol/g) & $6.08 \pm 5.80$ & $14.50 \pm 6.12$ & * & $20.02 \pm 7.25$ & ** & 0.007 \\
\hline
\end{tabular}

For control and $C 4$ groups, $n=6$. For liver $C 2$ and kidney $C 2, n=5$. For serum $C 2, n=4$.

1049 9-cis-4-oxo-13,14-dihydro-retinoic acid (9-cis-4-oxo-13,14-dh-RA).

1050 a Comparison between groups was performed using one-way analysis of variance (ANOVA).

$1051 *$ Group significantly different vs control group according to linear contrast tests, after significant 1052 ANOVA.

1053 b Some concentrations were close to or below the limit of detection, but were regardless calculated to 1054 allow statistical analysis. 
1058<smiles>C#COc1c(C(=O)N(C(=O)C=C)C(=O)c2ccccc2)c(=O)n(C)c2cccc(Cl)c12</smiles>

IMA-08401

(C2)<smiles>Cn1c(=O)c(C=O)c(O)c2c(Cl)cccc21</smiles>

IMA-06201

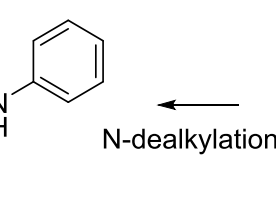<smiles>CCN(CC)c1ccccc1</smiles>

Laquinimod
1059

1060

1061

1062

1063

1064

1065<smiles>Clc1cc2c(cc1Cl)Oc1cc(Cl)c(Cl)cc1O2</smiles>

TCDD

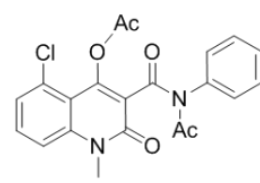

IMA-08401

(C2)

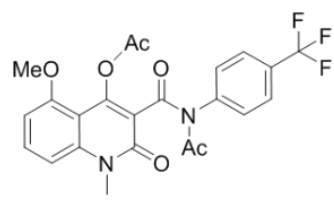

IMA-07101

(C4)

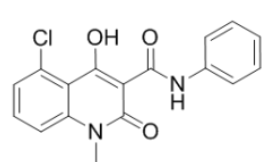

IMA-06201

(C1)

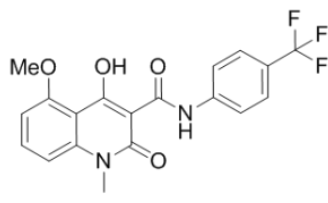

IMA-06504

(C3)
Fig. 2 Chemical structures of TCDD, C2 and C4, and those of the respective deacetylated metabolites $\mathrm{C} 1$ and $\mathrm{C} 3$ (used in in vitro assays) 

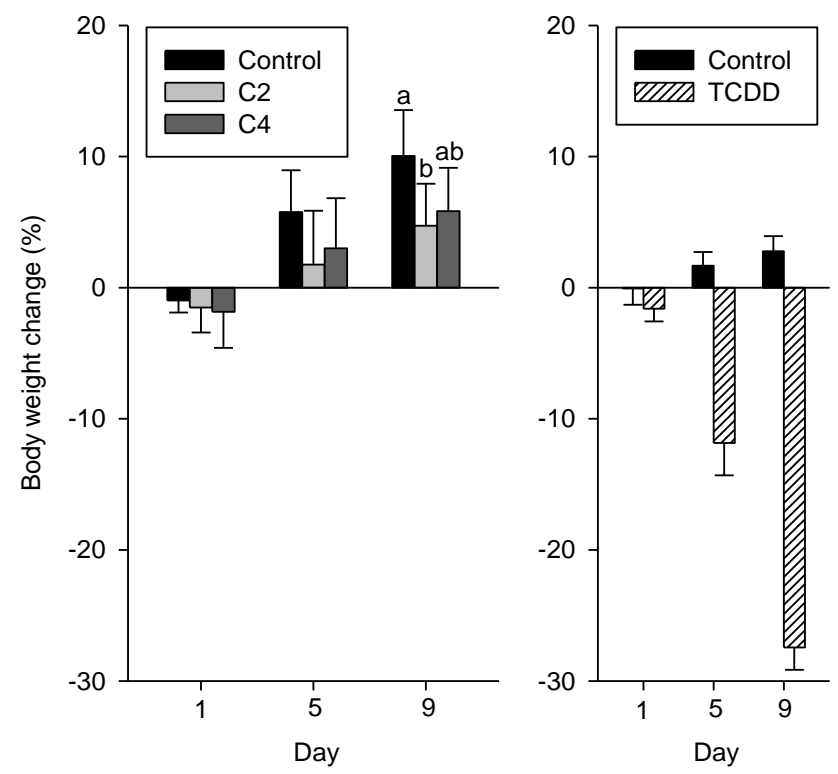

Fig. 3 Left panel. The effect of C2 and C4 on BW (S-D rats; $n=5-6$, mean \pm SD) on days 1,5 and 9 after the beginning of exposures (day 0). C2 (100 mg/kg/day) and C4 (75 mg/kg/day) were administered ig on five consecutive days (days $0-4$ ). The data in columns with different letters differ significantly from one another ( $p<0.05$, one-way ANOVA/Tukey HSD). Right panel. Typical pattern of body weight loss in TCDD-induced wasting syndrome for comparison with the changes caused by C2 and C4. These data originate from a previous study (Lindén, et al. 2014), where TCDD-sensitive L-E rats were exposed to a single ig dose of $100 \mu \mathrm{g} / \mathrm{kg}$ TCDD (no statistical analysis was conducted)

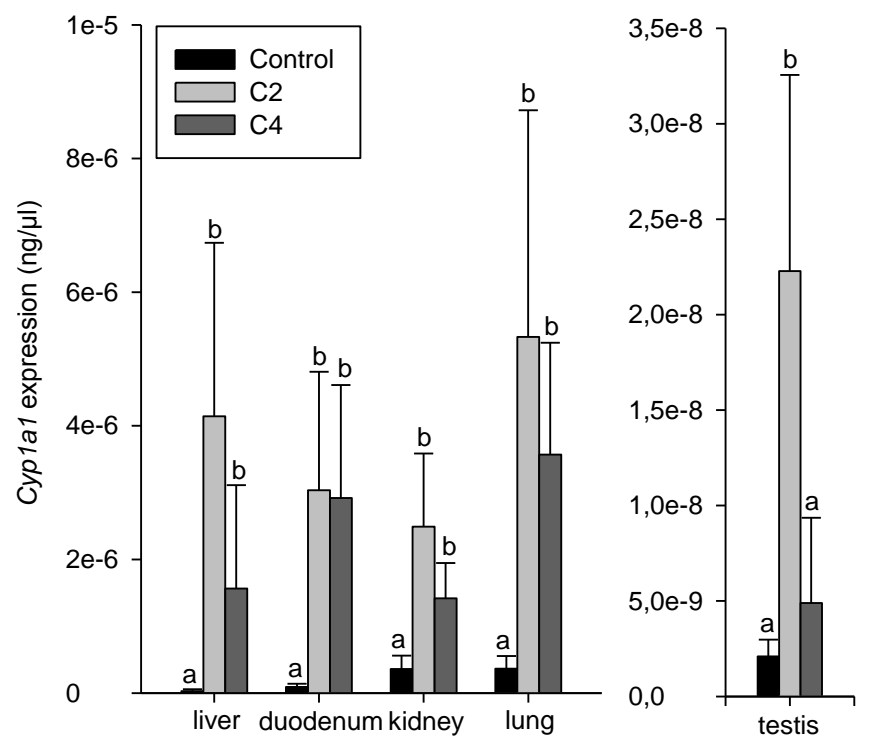

Fig. 4 The expression of Cyp1a1 induced by C2 (100 mg/kg/day) and C4 $(75 \mathrm{mg} / \mathrm{kg} / \mathrm{day})$ vs. controls in liver, duodenum, kidney, lung and testis in S-D rats $(n=5-6$, mean $\pm S D)$. The rats were exposed to the study compounds for 5 consecutive days, and monitored for further 5 days before euthanasia and sample collection. Columns with unidentical letters differ significantly from one another $(p<0.05$, oneway ANOVA/Student-Newman-Keuls) 

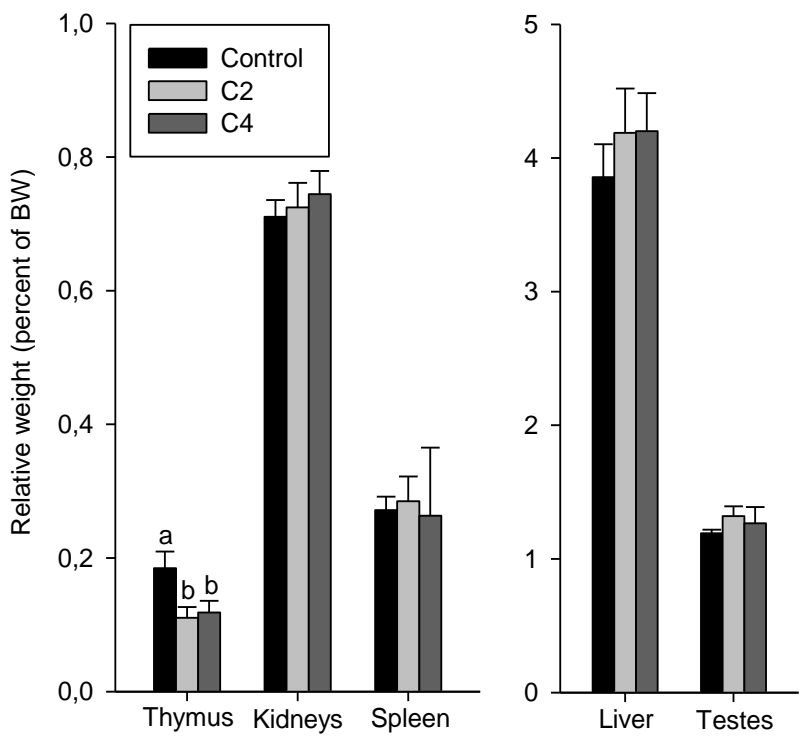

Fig. 5 Relative mean ( \pm SD) organ weights (percent of BW) of C2 (100 mg/kg/day), C4 (75 mg/kg/day) and control groups in S-D rats $(n=5-6)$. Both compounds were administered ig daily on days $0-4$, and the rats were euthanised on day 9 . The groups with unidentical letters differ significantly from one another ( $p<0.05$, one-way ANOVA/Student-Newman-Keuls)
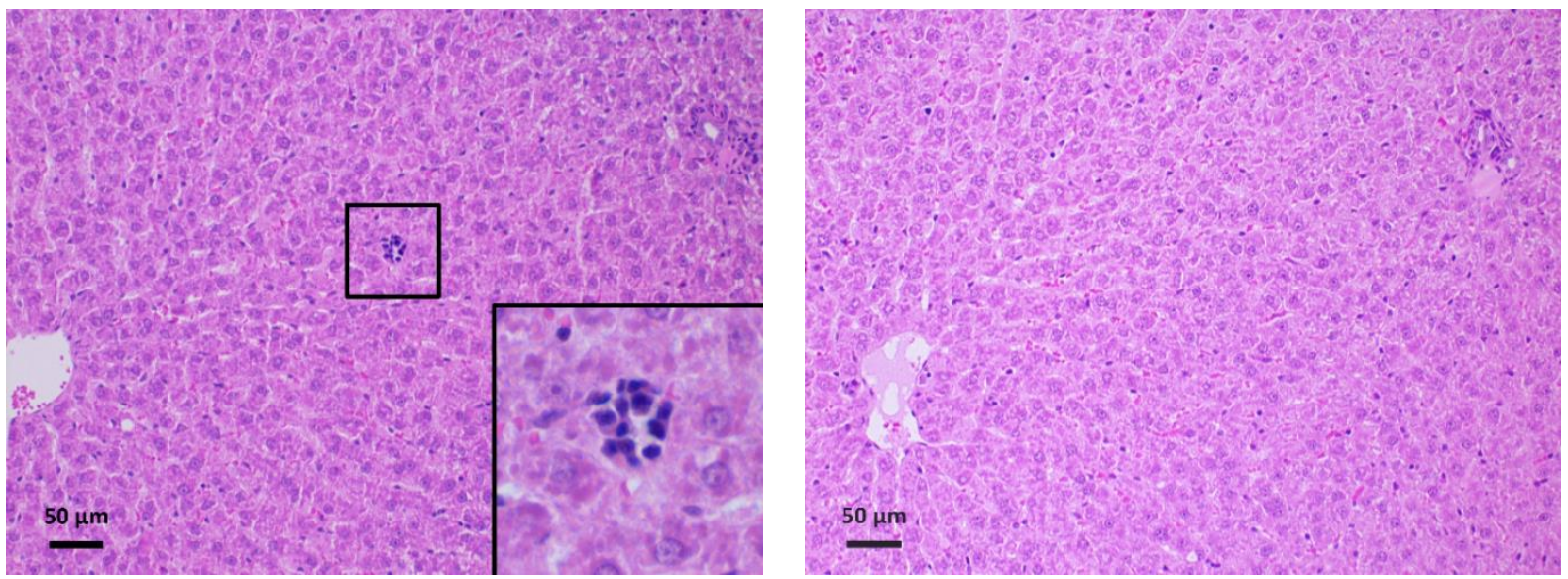

Fig. 6 Typical minimal hepatic EMH reaction with a lobular sinusoidal aggregate of deeply basophilic hematopoietic cells in $\mathrm{C} 2 / \mathrm{C} 4$ group rats in the subacute toxicity experiment (left panel), and a corresponding area with no alterations in the control group for comparison (right panel). Central vein in the left lower corner and portal triad in the right upper corner in both pictures. 

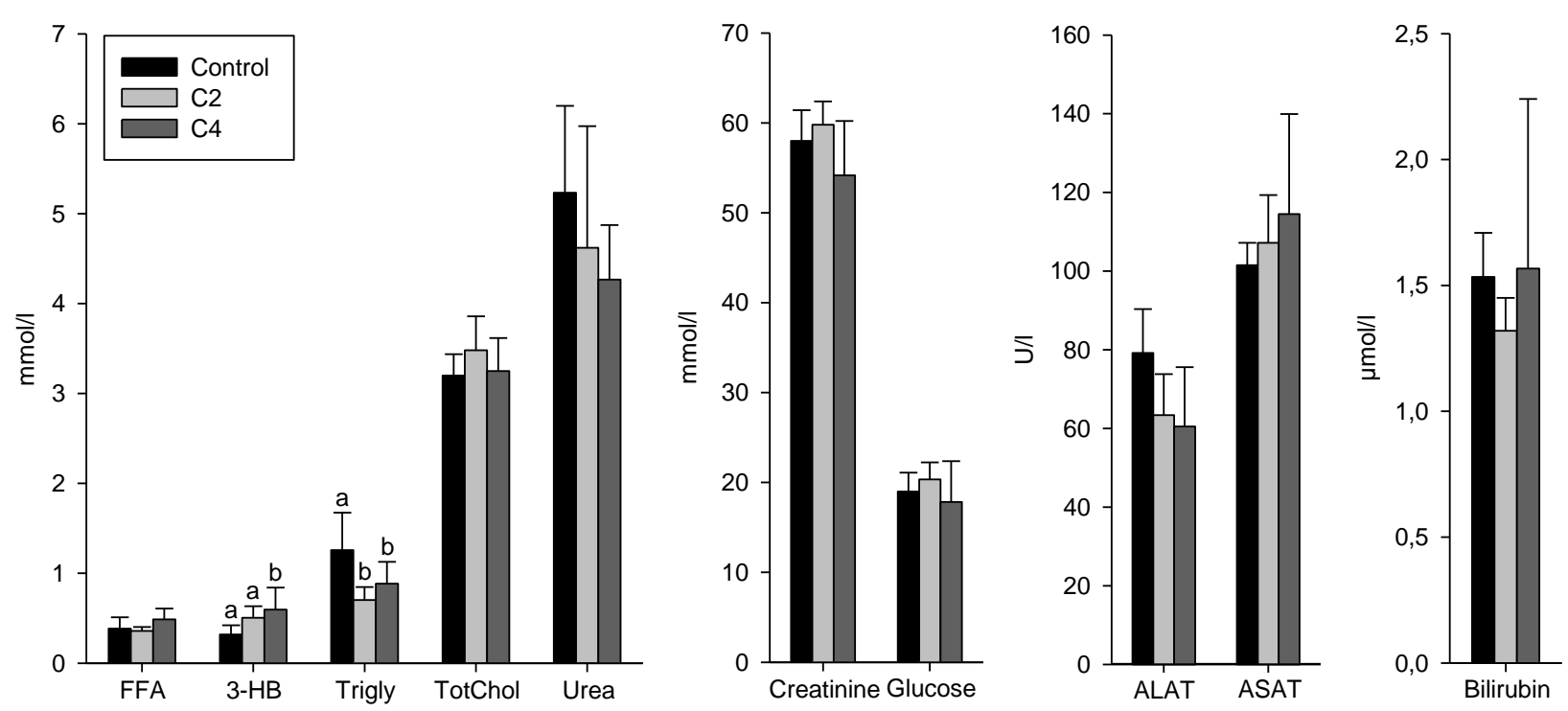

Fig. 7 Effects of C2 (100 mg/kg/day) and C4 ( $75 \mathrm{mg} / \mathrm{kg} /$ day) on biochemistry variables in S-D rats ( $\mathrm{n}=5-6$, mean $\pm S D$ ). Both compounds were administered ig daily on days $0-4$, and the rats were euthanised on day 9. The groups with unidentical letters differ significantly from one another $(p<0.05$, one-way ANOVA/Student-Newman-Keuls).

$\mathrm{FFA}=$ free

fatty acids,

3-HB=D-3-hydroxybutyrate, Trigly=triglycerides, TotChol=total cholesterol, ALAT $=$ alanine aminotransferase, ASAT $=$ aspartate aminotransferase

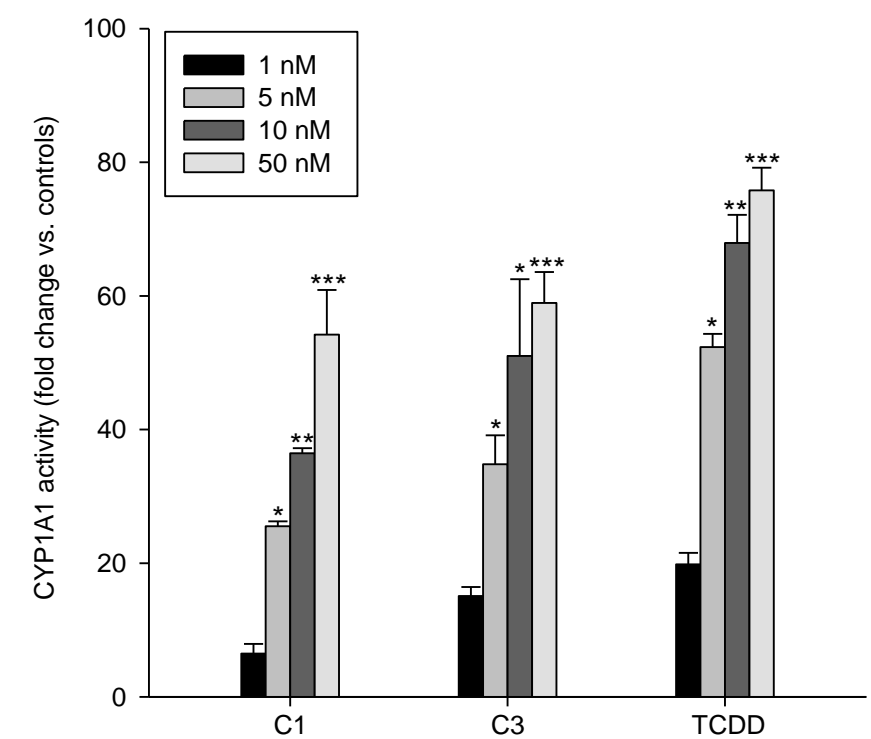

Fig. 8 In vitro CYP1A1 activity induced by $1,5,10$ or $50 \mathrm{nM}$ of $\mathrm{C1}, \mathrm{C3}$ or TCDD in the H4IIE hepatoma cell line, measured by a luminescent method. The data are portrayed as fold changes over controls $(n=3 ;$ mean $\pm S D) .{ }^{*}=p<0.05,{ }^{* *}=p<0.01, * * *=p<0.001$, Kruskal-Wallis non-parametric ANOVA followed by pairwise comparisons only with controls, therefore the $p$-values have not been adjusted. Two-way ANOVA showed a significant compound $x$ concentration interaction term, and at the 3 highest concentrations, TCDD differed significantly from C1 and C3 (see text for further details) 
Supplementary material for "Toxicological characterisation of two novel selective aryl hydrocarbon receptor modulators in Sprague-Dawley rats" by Selma Mahiout, Jere Lindén, Javier Esteban Mozo, Ismael Sánchez-Pérez, Satu Sankari, Lars Pettersson, Helen Håkansson and Raimo Pohjanvirta.

Corresponding author: Selma Mahiout, University of Helsinki, selma.mahiout@helsinki.fi

Supplementary Table 1 Primer sequences used in RT-qPCR runs. The primers were designed to span exonexon junctions to further eliminate amplification of genomic DNA

\begin{tabular}{lllll}
\hline $\begin{array}{l}\text { Target } \\
\text { gene }\end{array}$ & Forward primer-5' & Reverse-primer-3' & Amplicon (bp) & $\begin{array}{l}\text { Amplification } \\
\text { efficiency }\end{array}$ \\
\hline Cyp1a1 & gtcaggacaggaggctggac & gattgtgtcaaacccagctc & 101 & $0.89-1.04$ \\
Cyp1a2 & tcaaccatgatgagaagcagtg & actcagggtcttgtcgatgg & 95 & $0.94-0.96$ \\
Cyp1b1 & gctggatttggaggatgtgc & gcaggtaggctggtaaagagg & 111 & 0.97 \\
Cyp2b1 & ttgaccacccagacagcttc & acaaatgcgctttcctgtgg & 104 & $0.98-1$ \\
Ahrr & ctggcttcctgactatgcag & cgccacaatgcaaaacaagg & 116 & $0.91-0.97$ \\
Nqo1 & agggtcctttccagaataagaag & tgaattggccagagaatgacg & 115 & 1 \\
Tiparp & caactctcggggtctgaaag & cccaccaagtgtctgtaaatatgg & 148 & 0.95 \\
Ugt1 & aacgatctgcttggtcatcc & gcgttgtccatctgatcacc & 131 & $0.96-0.97$ \\
\hline
\end{tabular}

Supplementary Table 2 Body weight (BW) gain (\%, mean \pm SD) and relative (\% of terminal BW) thymus and liver weights (mean \pm SD) in the acute toxicity study. The rats received a single dose of vehicle, C2 or C4 (3 dose levels), and were euthanised 7-13 days later. BW gain at 7 days after exposure is shown relative to the weight (\%) on the day of exposure. Due to a low number of rats in the middle groups, only the highest dosage groups of $\mathrm{C} 2$ and $\mathrm{C} 4$ were statistically compared with the control (in bold). The groups with nonidentical letters differ significantly from one another $(p<0.05)$. Statistical analysis was performed by oneway ANOVA followed by Duncan's new multiple range test

\begin{tabular}{llllllll}
\hline & Control & \multicolumn{5}{c}{$\mathrm{C2}(\mathrm{mg} / \mathrm{kg})$} & $\mathrm{C} 4(\mathrm{mg} / \mathrm{kg})$ \\
\cline { 2 - 7 } & & 8.75 & 30.0 & $\mathbf{9 2 . 5}$ & 8.75 & 27.5 & $\mathbf{7 5 . 0}$ \\
$\mathrm{n}=6$ & $\mathrm{n}=1$ & $\mathrm{n}=2$ & $\mathrm{n}=3$ & $\mathrm{n}=2$ & $\mathrm{n}=2$ & $\mathrm{n}=3$ \\
\hline $\begin{array}{l}\text { BW gain } \\
(\% \pm \mathrm{SD})\end{array}$ & $11.8 \pm 2.6 \mathrm{a}$ & 12.6 & $12.0 \pm 0.1$ & $7.8 \pm 3.2 \mathrm{ab}$ & $11.9 \pm 0.1$ & $7.7 \pm 0.3$ & $6.1 \pm 1.8 \mathrm{~b}$ \\
$\begin{array}{l}\text { Thymus } \\
(\% \text { BW } \pm \text { SD) }\end{array}$ & $0.18 \pm 0.02 \mathrm{a}$ & 0.12 & $0.17 \pm 0.01$ & $0.12 \pm 0.01 \mathrm{~b}$ & $0.16 \pm 0.0$ & $0.15 \pm 0.02$ & $0.13 \pm 0.03 \mathrm{~b}$ \\
$\begin{array}{l}\text { Liver } \\
(\% \text { BW } \pm \text { SD) }\end{array}$ & $4.2 \pm 0.51$ & 4.3 & $4.2 \pm 0.04$ & $3.8 \pm 0.18$ & $4.3 \pm 0.08$ & $3.9 \pm 0.16$ & $3.8 \pm 0.19$ \\
\hline
\end{tabular}




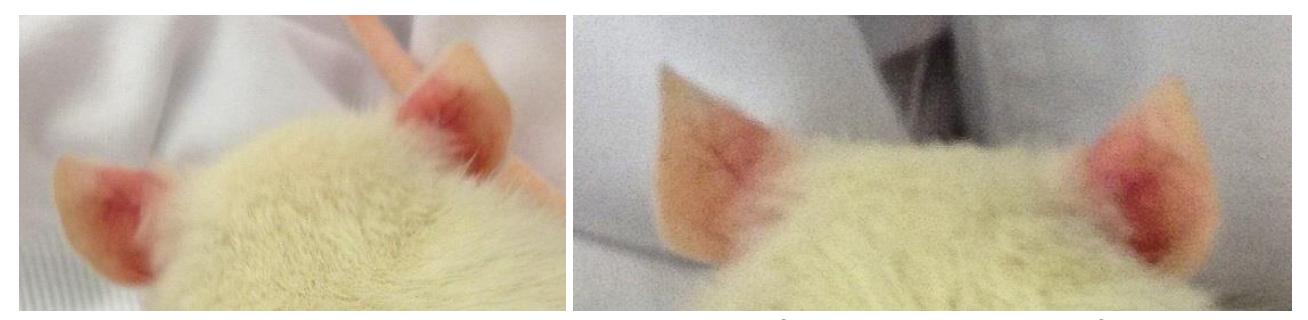

Supplementary Fig. 1 Transient hyperaemia of the ear pinnae inflicted by C2 $(100 \mathrm{mg} / \mathrm{kg} / \mathrm{day}$, 5 day repeated dosing) and $\mathrm{C} 4(75 \mathrm{mg} / \mathrm{kg} /$ day, 5 day repeated dosing), bilateral in the left panel and unilateral (right ear) in the right panel. The effect appeared on the first day after the repeated dosing regimen and persisted for 3-4 days. The pictures here were taken on the $3^{\text {rd }}$ day the effect was observed

Supplementary Table 3 Observed EMH in the spleen across groups $(n=5-6)$ in the subacute toxicity study. The severities of findings were graded on a scale of 1 to 4 as minimal, mild, moderate or marked, respectively. The grades of severity for microscopic findings were subjective; minimal was the least extent discernible

\begin{tabular}{llll}
\hline Grade & Controls & C2 $(100 \mathrm{mg} / \mathrm{kg} /$ day $)$ & C4 $(75 \mathrm{mg} / \mathrm{kg} /$ day $)$ \\
\hline None (0) & $1 / 6$ & - & - \\
Minimal (1) & $1 / 6$ & $1 / 5$ & $1 / 6$ \\
Mild (2) & $2 / 6$ & $3 / 5$ & $2 / 6$ \\
Moderate (3) & $2 / 6$ & $1 / 5$ & $3 / 6$ \\
Marked (4) & - & - & - \\
\hline
\end{tabular}

Supplementary Table 4 Thyroxine absorbances (mean $\pm S D ; n=5-6$ ) in sera collected upon termination of the subacute toxicity test in S-D rats, determined with an ELISA kit. For comparison and verification of the method, as a positive control, sera from TCDD sensitive L-E rats collected at 10 days after exposure to 100 $\mu \mathrm{g} / \mathrm{kg}$ TCDD or the vehicle (Lindén et al. 2014) were run on the same ELISA plate and handled identically to the actual samples. Statistical analysis was performed using Kruskal-Wallis non-parametric ANOVA or Mann-Witney U test

\begin{tabular}{llllll}
\hline Strain & Control & C2 & C4 & TCDD & p-value \\
\hline S-D & $0.81 \pm 0.11$ & $0.80 \pm 0.21$ & $0.75 \pm 0.13$ & - & 0.426 \\
L-E & $0.99 \pm 0.09$ & - & - & $2.16 \pm 0.13$ & 0.008 \\
\hline
\end{tabular}

